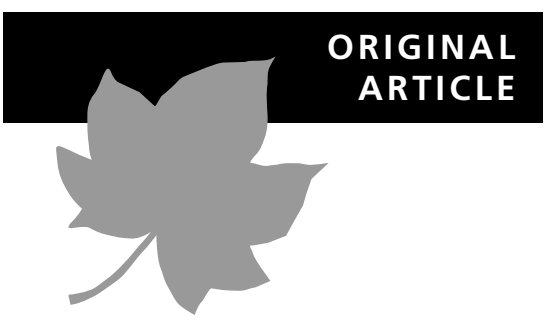

\title{
The 'oriental' component of the Balkan flora: evidence of presence on the Thracian Plain during the Weichselian late-glacial
}

\author{
E. K. Magyari ${ }^{1,2}$, J. C. Chapman ${ }^{1}$, B. Gaydarska ${ }^{1}$, E. Marinova ${ }^{3}$, T. Deli ${ }^{4}$, \\ J. P. Huntley ${ }^{1}$, J. R. M. Allen ${ }^{2}$ and B. Huntley ${ }^{2 *}$
}

\begin{abstract}
${ }^{1}$ Department of Archaeology, Durham University, Durham, UK, ${ }^{2}$ School of Biological and Biomedical Sciences, Durham University, Durham, UK, ${ }^{3}$ Laboratory of Palynology, Department of Botany, Faculty of Biology, Sofia University, Sofia, Bulgaria and ${ }^{4}$ Munkácsy Mihály Museum, Department of Natural Sciences, Békéscsaba, Hungary
\end{abstract}

${ }^{*}$ Correspondence: Brian Huntley, School of Biological and Biomedical Sciences, Durham University, South Road, Durham DH1 3LE, UK. E-mail: brian.huntley@durham.ac.uk

\begin{abstract}
Aim To obtain palaeobotanical evidence enabling evaluation of the viability of the hypothesis that the 'oriental' element of the Balkan flora reached south-east Europe from Turkey prior to the Holocene, probably via the Thracian Plain during a late Quaternary glacial stage but no later than the late Weichselian.
\end{abstract}

Location Ezero wetland, northern Thracian Plain, Bulgaria.

Methods We undertook analyses of pollen and microspores, plant macrofossils, wood fragments and molluscs recovered from sediments deposited in the Ezero wetland during the late Weichselian and Weichselian late-glacial. Sediment chronology was determined using radiocarbon age estimates.

Results Six metres of sediments were recovered from the basin, of which the lower $3 \mathrm{~m}$, extending from $c$. 15,450 cal yr вр to the early Allerød, was analysed. A major hiatus occurred after c. 13,900 cal yr вр, the overlying sediments being of late Holocene age. Palaeobotanical evidence indicates predominantly open vegetation during the Weichselian late-glacial, although macrofossil remains of woody taxa demonstrate the local presence of patches of wooded steppe and gallery forest. Changes in the composition of the steppe vegetation, and in the nature of the sediments deposited in the basin, indicate changes in climatic conditions, especially in the hydrological regime and in the moisture available to vegetation. After an initially relatively moister phase, the final centuries of the late Weichselian were drier, as was a short interval that may correlate with the Older Dryas. Moister conditions characterize intervals corresponding to the Bølling and Allerød sub-units of the Weichselian lateglacial interstadial. Although the pollen evidence is thus consistent with that from previous studies of this period in south-east Europe and south-west Asia, indicating predominantly open steppe vegetation, the macrofossil evidence indicates the persistent local presence of woody taxa. The woody taxa recorded include Celtis tournefortii-type and Juniperus cf. J. excelsa, two taxa today characteristic of the wooded steppes of Anatolia and members of the 'oriental' element of the southern Balkan flora, as well as Rosaceae Subfams. Maloideae and Prunoideae, Alnus and Fraxinus.

Main conclusions The late Weichselian vegetation of the northern Thracian Plain included patches of wooded steppe that supported members of the 'oriental' element of the modern Balkan flora. The presence of such taxa renders viable the hypothesis that they could have reached south-east Europe from Turkey via the Thracian Plain during glacial times. Such hypotheses in historical biogeography can be evaluated critically using the evidence obtained from plant macrofossil analyses in combination with that from pollen analysis.

\section{Keywords}

Celtis tournefortii-type, Irano-Pontic, Juniperus excelsa, late Weichselian, plant macrofossils, pollen analysis, Thracian Plain, Weichselian late-glacial. 


\section{INTRODUCTION}

The Balkan Peninsula has long been noted for the diversity of its flora and fauna. In accounting for this diversity, the role of the region as the principal area of persistence of many European temperate taxa throughout both glacial and interglacial stages of the Quaternary has often been emphasized (Bennett et al., 1991; Tzedakis et al., 2002; Tzedakis, 2004). More recently, a series of studies, principally of various temperate tree and shrub taxa, has shown that this element of species diversity is mirrored by intra-specific diversity at the allelic level (Vendramin et al., 1999; Brewer et al., 2002; Palme \& Vendramin, 2002; Petit et al., 2002; Grivet \& Petit, 2003; Heuertz et al., 2004), supporting the hypothesis of the longterm persistence of these taxa in this region (Petit et al., 2003). However, such taxa represent only one of the four major components of the floristic diversity of the region. The other major components are: Balkan endemics, some of them of Tertiary relict origin; central European, including Alpine, species; and species with a Mediterranean distribution. Furthermore, species with Pontic distributions and species distributed principally in Asia Minor, hereafter referred to as 'oriental' species, also are an important, albeit numerically smaller, component of the flora (Polunin, 1980). It has been hypothesized that these latter species extended their ranges into the Balkan Peninsula by migration from the east during intervals in the past when the sea level in the Mediterranean basin was lower than it is at present, principally either across the landbridge of Thrace or across the land masses that existed in the central and southern Aegean region (Turrill, 1929). The importance of the former route is considered to be reflected by the westward extension of the ranges of some plant species into the Balkan Peninsula only in Thrace; Turrill (1929, p. 374) lists 47 such species.

Given that the oriental species are predominantly adapted to relatively continental steppe or wooded steppe environments, it is possible that the wide extension of vegetation of these types throughout the lowlands around the Mediterranean basin during late Quaternary glacial stages (van Andel \& Tzedakis, 1996; Huntley et al., 2003), the relatively continental climate of these stages in this region (Allen et al., 1999, 2000), and the reduction in sea level by $c .120 \mathrm{~m}$ during glacial maxima (Fairbanks, 1989) might have provided a series of opportunities for the hypothesized westward range expansions of these species, not only into the Balkan Peninsula but potentially also farther west around the Mediterranean basin. Alternatively, as other authors have argued, the oriental species of the Balkans, and those taxa that provide biogeographical links between the Pontic region or Asia Minor and areas farther west in the Mediterranean basin, may be of Tertiary relict origin, reflecting a period in the late Tertiary when steppic environments and taxa were widespread from Central Asia westwards around the Mediterranean basin as far as the Iberian Peninsula. Ribera \& Blasco-Zumeta (1998), for example, favoured this hypothesis when discussing the origins of the biogeographical links between the insect faunas of steppic regions of the Iberian Peninsula and Central Asia. In reality, and given the many major climatic fluctuations of the Quaternary, it is likely that species differ in the origin and age of their present distribution patterns, with some being Tertiary relicts, some having expanded westwards during earlier Quaternary glacial stages, and others having expanded westwards into southern Europe when steppe conditions last were extensive in the region during the Weichselian late-glacial.

A necessary part of the evaluation of these alternative hypotheses, at least in relation to the oriental component of the Balkan flora, is to establish whether, prior to the Holocene, and in particular during the Weichselian late-glacial, and by analogy also during interstadials of the Weichselian and earlier glacials when southern European environmental conditions and palaeovegetation were similar to those during the Weichselian late-glacial (Allen et al., 1999; Brauer et al., 2007), environmental and ecological conditions in Thrace were suitable for the hypothesized westward migration of oriental species through this region into the Balkan Peninsula. The Thracian Plain is an extensive lowland area extending from north-west Turkey and north-east Greece north to southern Bulgaria (Fig. 1). Palynological evidence from Tenaghi Philippon (Bottema, 1978, 1979; Tzedakis et al., 2004), situated on the Drama Plain that forms the westward extension of the Thracian Plain into north-east Greece (Fig. 1), indicates that the Weichselian late-glacial vegetation in that area was predominantly herbaceous steppe. Palynological studies of cores XK-120 and A-159 from the south-west Black Sea, east of southern Bulgaria (Fig. 1), also indicate steppe vegetation dominated by Artemisia, ${ }^{1}$, Chenopodiaceae and Gramineae on the adjacent land area during the Weichselian late-glacial (Atanassova, 2005). In this case, such vegetation persisted into the early Holocene, only being replaced by mesic forest when the Mediterranean sea level rose sufficiently to overflow the Thracian landbridge $c$. $8000 \mathrm{cal} \mathrm{yr} \mathrm{BP,} \mathrm{after} \mathrm{which} \mathrm{time} \mathrm{the}$ water level rose also in the Black Sea. Although it has been speculated that vegetation of a similar steppic character, dominated by Chenopodiaceae, Artemisia and Gramineae and with only scattered woody taxa of a xerophytic character, mainly Juniperus and Ephedra, was present during the Weichselian late-glacial elsewhere in the Thracian Plain, including in the northern part of the Plain in Bulgaria (Bozilova et al., 1996; Palamarev, 2002), there are no palaeoecological data from within the region to support or refute such speculation.

The overall aim of the present study, therefore, was to obtain palaeovegetation and palaeoenvironmental evidence from a locality situated centrally within the northern part of the Thracian Plain that would allow us to test the hypothesis that members of the oriental element of the Balkan flora, and in particular woody members of that element, were able to grow in the region during the Weichselian late-glacial, and thus may

${ }^{1}$ Except where an authority is explicitly indicated, higher plant nomenclature follows 'Flora Europaea' (Tutin et al., 1964, 1968, 1972, 1976, 1980, 1993). 


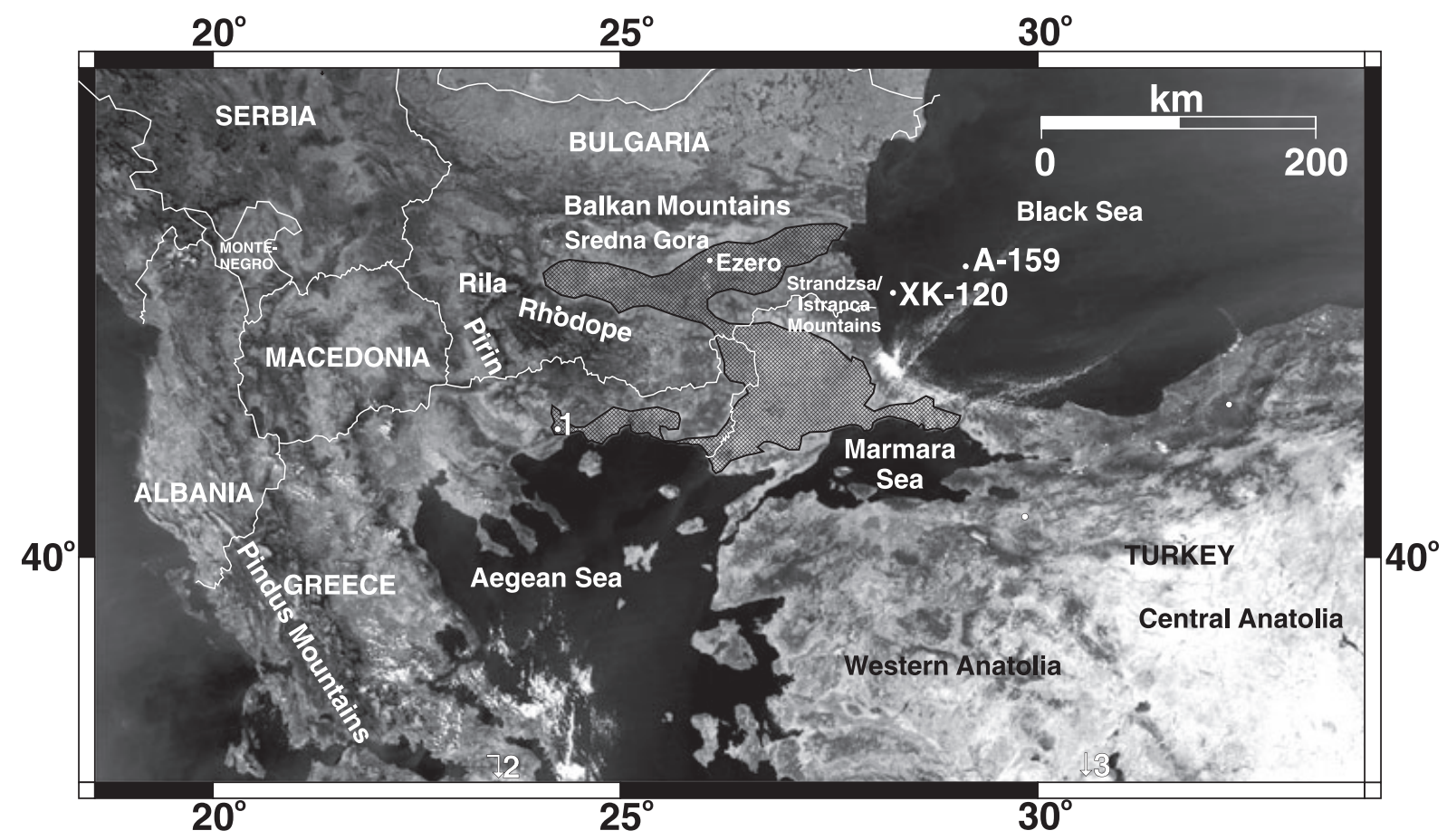

Figure 1 Satellite remote-sensed image of south-east Europe. Geographical features referred to in the text are labelled, and the locations of the Ezero wetland and of the other principal sites discussed are indicated (1, Tenaghi Philippon; 2, Franchthi Cave 3, Öküzini Cave). The area of the Thracian Plain is cross-hatched. [White areas, notably over the south-west Black Sea, where they form striking linear features, are clouds. Image modified from a full-colour MODIS (Moderate Resolution Imaging Spectroradiometer) image obtained on 21 September 2003 by the sensor onboard the Aqua satellite and downloaded from http://www.visibleearth.nasa.gov/view_rec.php?id=5850.]

have migrated into the Balkan Peninsula by this route during that interval or during some previous interval of similar environmental conditions in the region. A secondary objective was to seek evidence that woody members of the element were indeed present in Thrace at that time.

\section{STUDY SITE}

The Thracian Plain extends north to the southern flanks of the Balkan Mountains (Fig. 1). These mountains today coincide with a major climatic boundary: to the north, European continental air masses predominate, whereas to the south, Mediterranean air masses are also important (Velev, 2002). Biogeographically, these mountains mark the northern range limit for a number of those species in the oriental element of the Balkan flora listed by Turrill (1929) as extending only to Thrace; Figure 2 illustrates two examples of such species that represent links between the vegetation of Thrace and that of Asia Minor and the Middle East (Zohary, 1973; Polunin, 1980). The present flora of the Thracian Plain also includes a number of species representative of a Mediterranean element; together with the oriental floristic element, these species reflect the occurrence of moderate summer drought in the region.

The climate of the Thracian Plain was classified by Velev (2002) as 'intermediate continental', with hot summers and relatively mild winters. The mean annual temperature is c. $12.5^{\circ} \mathrm{C}$, with a coldest month (January) mean of $c .0-1^{\circ} \mathrm{C}$ and a warmest month (July) mean of c. $24^{\circ} \mathrm{C}$ : such a large range between the coldest and warmest month means is typical of a relatively continental climate. The mean annual precipitation is c. $520-560 \mathrm{~mm}$ (Kirilova, 1985; Velev, 2002), with June being the wettest month and August the driest. A secondary rainfall peak in November reflects the Mediterranean influence on the regional climate.

The predominant potential natural vegetation of the region is classified by Polunin (1980) as 'East-central European transitional (Continental)' deciduous forest. The extent of such natural vegetation is, however, limited as a result of human activities, being represented mainly by relict stands of deciduous Sub-Mediterranean forest with a mixed canopy including Quercus pubescens, Q. virgiliana, Q. cerris, Q. frainetto, Carpinus orientalis and Fraxinus ornus (Turrill, 1929; Bondev, 1991; Palamarev, 2002), and a field layer rich in Cotinus coggygria. South of the Maritza River-Bourgas line (Velev, 2002), vegetation of a more Mediterranean character also occurs, dominated by mixtures principally of Quercus coccifera, Phillyrea latifolia, Juniperus excelsa M.-Bieb. (Adams, 1999, 2001) and J. deltoides R.P. Adams (Adams et al., 2005). The herbaceous steppe vegetation that is found in the study area today is considered to be secondary, and to have developed following deforestation and former human land use (Nam, 1995).

The study site, referred to here as the Ezero wetland $\left(42^{\circ} 28^{\prime} \mathrm{N}, 26^{\circ} 1^{\prime} \mathrm{E} ; 124 \mathrm{~m}\right.$ a.s.l.), lies close to the northern margin of the Thracian Plain in Bulgaria. It is situated adjacent 
E. K. Magyari et al.

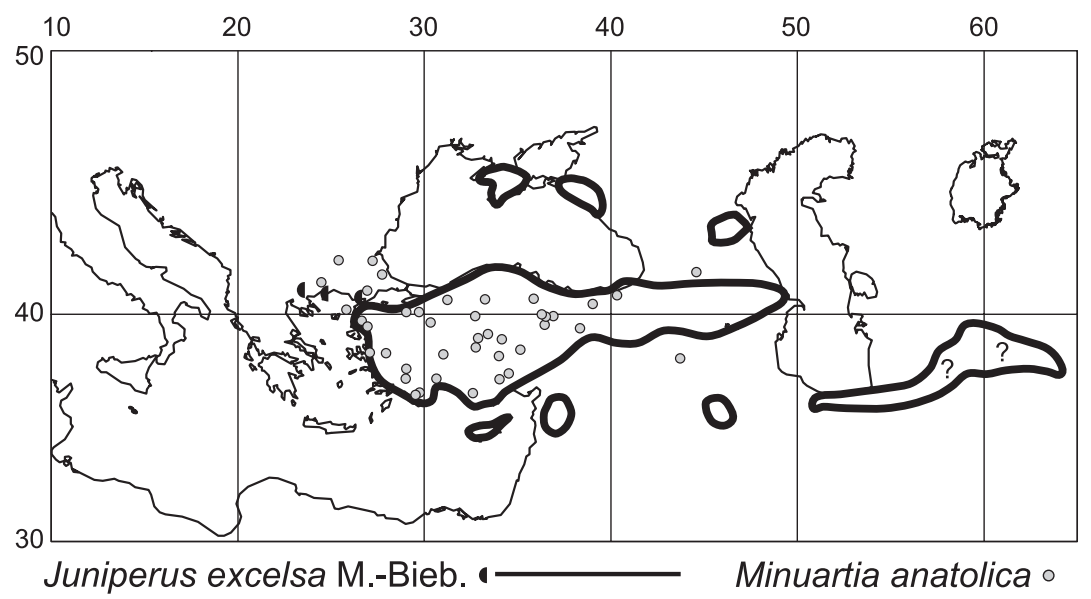

Figure 2 Distributions of two members of the 'oriental' element of the flora of south-east Europe. Both species today have their centre of distribution in south-west Asia but extend to the Thracian Plain at their north-western range limit. Distributions were redrawn from McNeill (1963), Farjon (1992), Tutin et al. (1993) and Jalas \& Suominen (1973, 1983). [The extent of the distribution of Juniperus excelsa M.-Bieb. in Iran and Turkmenistan (area indicated by question marks on the map) is uncertain because of potential confusion with the closely related J. polycarpos K. Koch in this region.] Axis annotations indicate degrees of longitude (east) and latitude (north).

to the archaeological site of Ezero-Dipsis, a tell site occupied between c. 6270 and 4800 cal yr BP (Dennell, 1978; Georgiev et al., 1979), c. $1 \mathrm{~km}$ north-east of the present Ezero village and c. $3 \mathrm{~km}$ south-east of Nova Zagora (Fig. 3). The geology of the area comprises Neogene lacustrine and alluvial sediments (Nedialkov, 1985; Angelova et al., 1993) overlying a deeply indented palaeo-relief formed by Paleogene volcanic and sedimentary rocks. At Ezero, the Neogene sediments are underlain by a narrow band of dolomites (Bosnek Formation, Triassic). Springs discharging karst water are frequent along this formation, and the Ezero wetland receives water from approximately five springs according to our field observations and to local people (T. Tshanev, personal communication). Elderly people from Ezero village recall the wetland during the early part of the 20th century as a chain of five to seven springfed pools, separated by narrow bands of meadow, the pools never freezing in winter. The position of the springs has become obscured in recent years as a result of overgrowth of the pools by reed-swamp vegetation following construction of a pumping station in the 1970s (T. Orehova, personal communication). Figure 3 shows the approximate position of the pools before water regulation; the sediment core (EZ-2) from which the data presented below were obtained sampled the sediments of the largest pool, Lake Baj Petko.

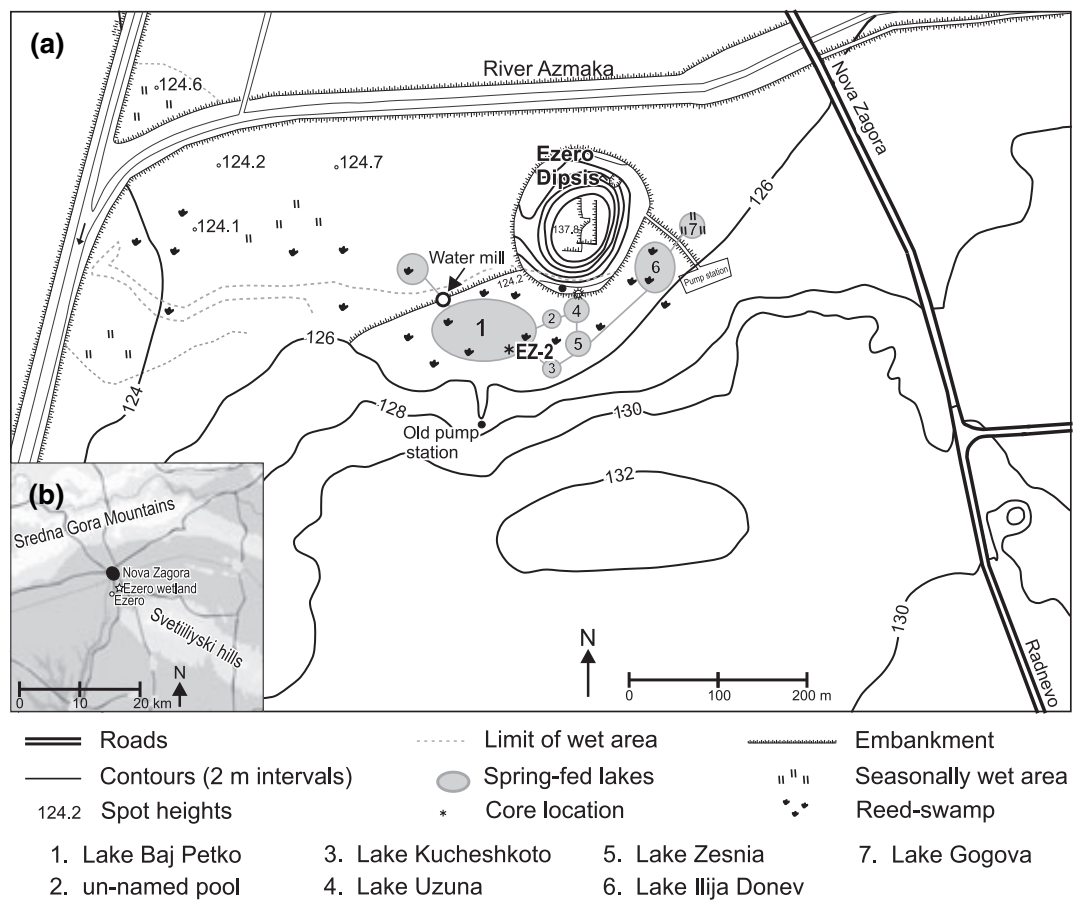

Figure 3 Location map of the study site. (a) Local features and relief in the immediate vicinity of the Ezero wetland; Ezero-Dipsis is the tell that has been the subject of archaeological investigations. (b) Principal features and relief of the region surrounding the study site. 
The 'oriental' component of the Balkan flora

Table 1 Accelerator mass spectrometry ${ }^{14} \mathrm{C}$ age estimates obtained from Ezero wetland core EZ-2.

\begin{tabular}{lllllc}
\hline Depth $(\mathrm{cm})$ & Material dated & Weight $(\mathrm{g})$ & $\begin{array}{l}\text { Laboratory } \\
\text { sample code }\end{array}$ & $\begin{array}{l}\text { Age estimate } \\
\left({ }^{14} \text { C yr вP }\right)\end{array}$ & $\begin{array}{l}\text { Calibrated age estimate } \\
(\text { cal yr вP, 2 } \sigma \text { range })\end{array}$ \\
\hline $50-52$ & Wood charcoal fragments & $12 \cdot 03$ & Poz-1931 & $110 \cdot 6 \pm 0 \cdot 5$ & Modern \\
$165-167$ & Monocotyledon leaf fragments & $2 \cdot 54$ & Poz-1932 & $1315 \pm 35$ & $1290-1220$ \\
$260-265$ & Sambucus ebulus seed fragments & $2 \cdot 71$ & Poz-12215 & $2970 \pm 30$ & $3260-3000$ \\
$287-289$ & Wood fragments & $7 \cdot 24$ & Poz-1933 & $3000 \pm 35$ & $3330-3070$ \\
$340-345$ & Monocotyledon leaf fragments & $0 \cdot 83$ & Poz-13602 & $8060 \pm 50$ & $9130-8760$ \\
$390-393$ & Various macrofossils (> 180 $\mu \mathrm{m})$ & $2 \cdot 59$ & Poz-2734 & $11,750 \pm 60$ & $14,060-13,440$ \\
$420-425$ & Monocotyledon leaf fragments & $2 \cdot 43$ & Poz-13603 & $12,390 \pm 60$ & $14,850-14,100$ \\
$460-465$ & Monocotyledon leaf fragments & $0 \cdot 91$ & Poz-13604 & $10,000 \pm 50$ & $11,710-11,260$ \\
$510-515$ & Monocotyledon leaf fragments & $1 \cdot 98$ & Poz-13605 & $12,930 \pm 60$ & $15,600-15,000$ \\
$547-549$ & Bulk sediment & $25 \cdot 71$ & Poz-1934 & $13,030 \pm 70$ & $15,800-15,050$ \\
$576-579$ & Celtis fruit stones & $2 \cdot 01$ & Poz-12190 & $12,900 \pm 60$ & $15,550-14,950$ \\
\hline
\end{tabular}

The landscape around the Ezero wetland generally has a low relief and lies c. 120-150 m a.s.l., although the Svetiiliyski Hills to the south-east of the site rise to $c .500 \mathrm{~m}$ a.s.l. and the more distant Sredna Gora to the north and north-west rise to over $1500 \mathrm{~m}$ a.s.l. (Fig. 3). The wetland is bordered to the north by the River Azmaka. This was formerly extremely sinuous, running through a very poorly drained flood plain; during the past 50 years, however, it has been artificially straightened and drainage of the surrounding land much improved (Dennell, 1978). The soils of the area are mainly diluvial sandy soils, smolnitsa (alluvial soils) or cinnamonic forest soils (Kirilova, 1985). Diluvial sandy soils occur at the foot of the Sredna Gora and Svetiiliyski Hills as fans or shelves and are derived from hill materials re-sorted by erosion (Dennell, 1978). Such diluvial sands were deposited in the area surrounding the Ezero wetland, but are today overlain by a thick sheet of riverine clay (Dennell, 1978). Smolnitsa are developed on the poorly drained lacustrine and alluvial sediments of the Azmaka flood plain (Kirilova, 1985). Cinnamonic forest soils predominate in well-drained areas outside the influence of erosion from the uplands.

The vegetation of the Ezero wetland itself, like that of other wetlands in the surrounding area, is today a reed-swamp dominated by Phragmites australis, Typha latifolia and T. angustifolia (Atanassova \& Marinova, 2005). The surrounding lowlands are intensively farmed, and the Svetiiliyski Hills too have been deforested and used for agriculture. Prior to deforestation, however, higher parts of these hills are likely to have supported forest stands, mainly of Quercus frainetto, Q. cerris and Ulmus minor (Kirilova, 1985). Relict trees reflecting the diverse composition of these former forests can still be found; for example, we found both Celtis glabrata Stev. ${ }^{2}$

\footnotetext{
${ }^{2}$ Note that C. glabrata Stev. from Bulgaria has in the past been identified incorrectly as C. caucasica Willd. (Browicz \& Zieliński, 1977, 1982), and is referred to by that name in many earlier accounts. Although Browicz \& Zieliński (1977) consider it unlikely that C. caucasica occurs either in Bulgaria or elsewhere in the Balkan Peninsula, the most recent Bulgarian Flora (Kozuharov, 1992) does not apply their identification criteria and identifies C. caucasica, rather than C. glabrata, as occurring in the region.
}

and C. australis L. growing in small woodland patches or in isolation on abandoned vineyard terraces.

\section{FIELD AND LABORATORY METHODS}

The sediments of the Ezero wetland were sampled during the summer of 2002 using a 7-cm-diameter Russian corer. Two cores were taken from the area of the largest of the former spring-fed pools, Lake Baj Petko (Fig. 3). A shorter core (EZ-1, $2 \cdot 85 \mathrm{~m}$ ) was obtained from the southern side of this basin, and a longer one was obtained in the western part of the basin (EZ2, $6.0 \mathrm{~m}$ ). Here we report the results of various analyses of the sediments of the latter core.

A chronological framework for the sediments of core EZ-2 was established using a series of $11{ }^{14} \mathrm{C}$ age determinations. Ten of the samples dated were terrestrial plant macrofossils, and one was a bulk sediment sample from a segment of the core from which no terrestrial plant macrofossils were recovered (Table 1). The ${ }^{14} \mathrm{C}$ age determinations were made at the Poznan Radiocarbon Laboratory using accelerator mass spectrometry (AMS). The ${ }^{14} \mathrm{C}$ ages obtained were calibrated into calendar years using the INTCAL98 calibration curve of Stuiver et al. (1998) as implemented in the program сацiв4.4.

The sediment lithology of the core was examined and described in the laboratory. Organic matter and inorganic carbonate contents of the sediments were estimated by measuring the loss-in-weight upon ignition at $550^{\circ} \mathrm{C}$ and $950^{\circ} \mathrm{C}$ of $0.5-\mathrm{cm}$-thick sub-samples taken at $5-\mathrm{cm}$ intervals (Heiri et al., 2001).

Macrofossil analyses were performed on 5-cm-thick sediment slices (sub-sample volume $30-45 \mathrm{~cm}^{3}$ ) taken at $10-\mathrm{cm}$ intervals. Sub-samples were wet-sieved through 2-mm, 1-mm, $500-\mu \mathrm{m}$ and $250-\mu \mathrm{m}$ meshes, and the material retained on each sieve examined separately. Plant macrofossils were identified to the lowest possible taxonomic level. Determinate entities, such as fruits and seeds, were counted, and estimates were made of the relative frequency of the principal components amongst the indeterminate macrofossils, such as leaf fragments. Fruits and seeds were identified using the keys and 'seed' atlases of Anderberg (1994), Beijerinck (1976), Berggren 
(1969, 1981), Katz et al. (1965), Schermann (1967) and Schoch et al. (1988). In addition, the plant macrofossil reference collections of the Department of Archaeology, Durham University, and the Department of Botany, Sofia University, were consulted where necessary. Critical determination to the species or species-group level was attempted for Juniperus seeds and Celtis fruit stones, because both genera include woody members of the oriental element of the Balkan flora. Matsutani's (1987) key was used, as well as examination of material in various seed collections. The Supplementary Material (Appendix S1) provides further details of these identifications. Mollusc remains were identified using the keys of Kerney et al. (1983) and Richnovszky \& Pintér (1979). Subfossil wood fragments $>2 \mathrm{~mm}$ were identified using the keys of Greguss (1972) and Schweingruber (1989), as well as by examination of reference material held at Sofia University and the University of Tübingen. Concentrations of fruits and seeds, molluscs and wood fragments were all standardized to a sediment sub-sample volume of $45 \mathrm{~cm}^{3}$.

Sediment sub-samples of $1 \mathrm{~cm}^{3}$ were taken at 8 -cm intervals for pollen and microspore analysis. Sub-samples were processed using standard procedures for the extraction of pollen and microspores (Moore et al., 1992). Treatment with $\mathrm{NaOH}$ and $\mathrm{HCl}$ was followed by treatment with $\mathrm{HF}$ and microsieving, retaining the material not passing through a $10-\mu \mathrm{m}$ mesh, prior to acetolysis, staining and dehydration. Pollen and microspore concentrations were determined by adding Lycopodium tablets to the sub-samples prior to commencing the extraction procedure (Stockmarr, 1971). Pollen and microspore identifications were made using the descriptions and identification keys in Moore et al. (1992) and Beug (2004), as well as by comparison with reference material in the collection of the School of Biological and Biomedical Sciences, Durham University. Counting continued until at least 500 terrestrial pollen grains had been identified. Pollen percentage values were expressed relative to the sum of all terrestrial pollen taxa. In the case of sub-samples from the depth range $400-450 \mathrm{~cm}$, in which Gramineae pollen was particularly abundant, the size of a sample of 100 Gramineae pollen grains was measured for each sub-sample. Both pollen grain and annulus diameters were measured; comparison with equivalent measurements of Phragmites australis pollen grains on reference slides was then used to assess the likely relative frequency of $P$. australis pollen in the fossil assemblages.

For both the pollen and plant macrofossil stratigraphic sequences, local assemblage zones were distinguished using the method of optimal partitioning (Birks \& Gordon, 1985) as implemented in the program psimpoll 3.00 (Bennett, 1992). The number of statistically significant assemblage zones was determined using the broken-stick model (Bennett, 1996). Stratigraphic diagrams were drawn using PSIMPOLL 3.00 .

\section{RESULTS}

Given the focus of the present study on elucidating palaeovegetation and palaeoenvironment in the region during the
Weichselian late-glacial, most results are presented only for the lower $3 \mathrm{~m}$ of the EZ-2 core, which represents this interval (see below).

\section{Sediment stratigraphy}

Four lithostratigraphic units were recognized in the lower $300 \mathrm{~cm}$ of core EZ-2 (Fig. 4). The lowermost unit (600$500 \mathrm{~cm}$ ) is dominated by organic rich silty medium sand and sandy silt, of which at least the sand component was probably derived by erosion of the extensive diluvial sandy soils in the area around the lake. It is possible that such soils formed the shore of the lake at this time, the riverine clays that now cover these deposits on the flood plain of the Azmaka being deposited at some later time, or alternatively that the sand was wind-blown from more distal exposures. The transition to the overlying unit $(500-460 \mathrm{~cm})$ is marked by a decrease in grain size; this unit comprises alternating peaty clayey silt and silty sand layers. The third unit $(460-390 \mathrm{~cm})$ is organic-rich peaty clay, probably indicating increased stability of the surrounding landscape as well as overgrowth of the core location by swamp vegetation. The transition to the fourth unit $(390-285 \mathrm{~cm})$ is very sharp, with a homogeneous clayey silt characterizing this uppermost unit. Compared with the sediments of the three underlying units, which generally are rich in plant macrofossils, and occasionally contain mollusc shells, the sediments of the fourth unit have a markedly lower abundance of macrofossils. The sharp lower boundary of this unit, together with the character of its sediments, suggests either a marked increase in lake water depth or a change in the sedimentary environment, perhaps to one of alluvial sedimentation (Brown, 1997). We exclude the first possibility because neither the pollen nor the macrofossil records of aquatic and wetland taxa (see below) are consistent with any substantial increase in water depth. Geomorphological information on channel migration and the phases of alluviation on the Azmaka flood plain (Dennell, 1978; Angelova et al., 1993), however, support the alternative suggestion. We therefore infer that the clayey silt sediments of the fourth unit were deposited as a result of seasonal flooding of the lake basin by the Azmaka river, and that the sharp transition from the underlying unit reflects a rapid onset of the new hydrological regime with which these floods were associated.

The sediments of the uppermost $15 \mathrm{~cm}$ of the fourth unit contain wood fragments mixed with daub (man-made building material) and medium sand, probably reflecting erosion from the adjacent tell. The top of the unit is marked by a very sharp transition to overlying sediments that are silty medium sands with occasional pebbles, shells and wood fragments.

\section{Chronology}

Details of the $11{ }^{14} \mathrm{C}$ age determinations obtained are given in Table 1, along with the calibrated ages of the samples measured, their depths, and the materials used. 
Figure 4 Age-depth relationship for the EZ-2 sediment core. The depth range spanned by each of the samples from the lower $300 \mathrm{~cm}$ of the core for which radiocarbon age estimates were obtained is indicated, as is the $2 \sigma$ range $(0.941$ probability) of the calithe sediment lithology is shown on the left, and the local terrestrial pollen (EZP-1 to EZP-5) and aquatic/wetland macrofossil (EZM-1 to EZM-5) assemblage zones are indicated on the right. The GRIP event stratigraphy (Björck et al., 1998) is shown below the age scale. The dotted line indicates the age-depth curve used to assign ages to zone boundaries in the lower $c .200 \mathrm{~cm}$ of the core (see text for details). brated age estimate. An outline description of

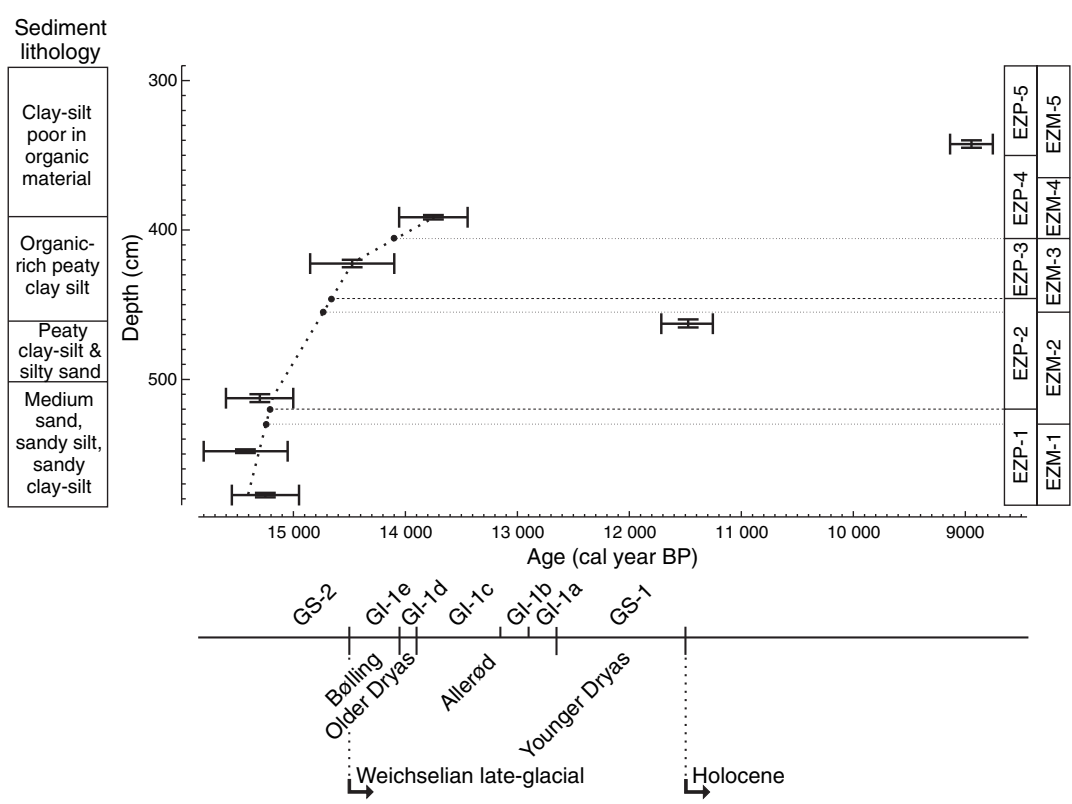

Three age estimates were obtained from the lowermost metre of the core, two of them for plant macrofossils and the third for a bulk sediment sample. Although the two macrofossil-derived estimates are for samples differing in depth by $60 \mathrm{~cm}$, their ${ }^{14} \mathrm{C}$ ages are indistinguishable $(12,900 \pm 60$ and $12,930 \pm 60{ }^{14} \mathrm{C}$ yr вр), indicating that sediment accumulated very rapidly in this part of the sequence, probably as a result of intense erosion of the surrounding hill slopes. The age estimate from the bulk sediment sample also is indistinguishable from either of those obtained from macrofossils, although its slightly older age estimate $\left(13,030 \pm 70{ }^{14} \mathrm{C}\right.$ yr $\left.\mathrm{BP}\right)$ may reflect the presence in the sample of remains of aquatic plants and/or micro-organisms that utilized bicarbonate ions $\left(\mathrm{HCO}_{3}{ }^{-}\right)$from the lake water as their carbon source. Given the association of the spring feeding the lake with a bed of dolomite, bicarbonate in the lake water will almost certainly be derived in part by dissolution of this carbonate rock that is infinitely old in ${ }^{14} \mathrm{C}$ age (Walker, 2005). Together these three age estimates indicate that sediment accumulation began in the lake c. 15,450 cal yr вр (Fig. 4).

Three further age estimates were obtained from the second and third sediment units. Whereas the upper two estimates are consistent with their stratigraphic positions, and provide a plausible sediment accumulation rate when taken together with the estimates obtained from the first unit, the third (Poz$\left.13604,10,000 \pm 50{ }^{14} \mathrm{C} \mathrm{yr} \mathrm{BP}\right)$, obtained from only $0.91 \mathrm{~g}$ of monocotyledon leaf fragments, is much younger than expected. We excluded this result when establishing the agedepth relationship for the core; we consider it most probable that the small amount of material from which this estimate was obtained was in part a contaminant, derived from a higher level in the sediments and carried down during the coring operation to the depth from which it was recovered. The two stratigraphically consistent estimates indicate a slightly decreased sediment accumulation rate between $515 \mathrm{~cm}$ and
$420 \mathrm{~cm}$, and a further and more marked decrease between $420 \mathrm{~cm}$ and $390 \mathrm{~cm}$.

Only a single age estimate was obtained from the fourth unit. It is once again younger than might have been expected (Poz-13602, $8060 \pm 50{ }^{14} \mathrm{C} \mathrm{yr} \mathrm{вP)} \mathrm{and} \mathrm{also} \mathrm{was} \mathrm{obtained} \mathrm{from}$ a very small $(0.83 \mathrm{~g})$ fragment of monocotyledon leaf. Although it might thus be rejected on the basis that the material was probably in part a contaminant, the nature of the sediments of the fourth unit, interpreted as alluvial sediments deposited during flooding of the lake basin by the Azmaka river, requires consideration of the possibility that these sediments were deposited discontinuously over several millennia, and that the age estimate is thus accurate.

The four further age estimates obtained from the upper $300 \mathrm{~cm}$ of the core indicate that this section of the core represents the late Holocene. Given (1) the presence of material probably derived from the tell in the uppermost sediments of the fourth unit, (2) the very sharp lithological transition at the top of this unit, (3) the absence of any evidence of anthropogenic indicators in the palaeovegetation record from the sediments of this unit (see below), and (4) an abrupt change in the regional palaeovegetation record at $290 \mathrm{~cm}$, from dominance of Pinus pollen to dominance by pollen taxa representing broadleaved summergreen trees with associated herbaceous taxa indicative of anthropogenic activity (EKM, unpublished data), we infer that there was a substantial hiatus in sediment accumulation at c. 300-290 cm, separating the majority of the fourth lithological unit from overlying late Holocene sediments. Given this inference, we also consider it most likely that the sediments of the fourth unit, with the exception of the uppermost $15 \mathrm{~cm}$, were deposited during the Weichselian late-glacial. On this basis, we reject the age estimate at $340-345 \mathrm{~cm}$ when fitting, by eye, the age-depth relationship for the lower $3 \mathrm{~m}$ of the core (Fig. 4); this relationship is thus based upon the five stratigraphically 
coherent ${ }^{14} \mathrm{C}$ age estimates obtained and takes into account the $2 \sigma$ ranges of their calibrated ages. The lack of a reliable age estimate from the fourth unit prevents us from making any inference of the age-depth relationship above $c .400 \mathrm{~cm}$.

\section{Biostratigraphy}

\section{Regional terrestrial vegetation}

The majority of the taxa recorded in the pollen and microspore data, along with the wood fragments and macrofossils of taxa not principally associated with wetland or aquatic habitats, provide the evidence upon the basis of which we have inferred the character of the vegetation in the surrounding region. The pollen diagram is shown in Figs 5 and 6 presents the data for macrofossils and wood fragments of terrestrial plant taxa. Five local pollen assemblage zones, EZP-1 to EZP-5, were distinguished, principally reflecting qualitative and quantitative changes in the dominant terrestrial pollen taxa. The boundaries of these zones are shown in Fig. 5, Whilst Fig. 6. Table 2 provides a summary of the principal characteristics of each zone, its depth and estimated age ranges, and the inferred character of the regional terrestrial vegetation.

The Gramineae pollen-grain size measurements made for samples from zone EZP-3, and a comparison of these results with measurements made on Phragmites australis reference material, indicate that the Gramineae percentage and concentration peaks in this zone cannot be ascribed to local growth of $P$. australis around the basin. The fossil assemblages are dominated by larger grains, leading us to interpret the peak in Gramineae as reflecting an increased extent of steppe grasslands in the surrounding region at this time.

\section{Local wetland vegetation}

Evidence of the nature of the local vegetation in and around Lake Baj Petko is provided by both the macrofossil and pollen records of wetland and aquatic plant taxa. Figure 7 presents the data for the relevant macrofossil remains, and the relevant pollen taxa are included in Fig. 5. Five local macrofossil assemblage zones, EZM-1 to EZM-5, were distinguished, and their boundaries are shown in Fig. 7. Table 3 provides brief descriptions of the key features of the record of local wetland and aquatic plant taxa during each of these zones, as well as the depth and estimated age ranges of each zone, a summary of the inferred character of the lake and the surrounding wetland, and an outline of the inferred nature of the local vegetation.

\section{Aquatic mollusc communities}

Mollusc shells were abundant only in the lower half of the sediments of zone EZM-1, between $600 \mathrm{~cm}$ and $560 \mathrm{~cm}$, although smaller numbers were recovered from the sediments of zones EZM-2 and EZM-5 (Fig. 7). The branchiate Valvata piscinalis was present only in the lower half of EZM-1, although it occurred there in large quantities. Bithynia tentaculata, Planorbis planorbis and Succinea oblonga were also found in this zone, each in a single sample. Valvata piscinalis is indicative of well-oxygenated mesotrophic conditions, whereas B. tentaculata is associated with calcareous waters. Both are often associated with aquatic plants, as is $P$. planorbis. Together they indicate that, during the first half of zone EZM-1, during the first century or two of sediment accumulation, the lake had calcareous well-oxygenated waters and probably also abundant aquatic plants. This is consistent with the abundant remains of Pediastrum, as well as with the general abundance of macrofossils of aquatic plants in these sediments, although most of the latter represent floating leaved and especially emergent or marginal species. The absence of $V$. piscinalis above $560 \mathrm{~cm}$ may indicate reduced oxygen levels in the lake. This would be consistent with the occurrence, albeit sparsely, only of P. planorbis in zones EZM-2 and EZM-5; this widespread species is tolerant of relatively anoxic waters and also often occurs in relatively eutrophic conditions. Succinea oblonga, which occurs only in the sample following the disappearance of $V$. piscinalis, is a land snail characteristic of damp sparsely vegetated places, often being found on bare muddy surfaces that have dried out (Kerney et al., 1979); it may indicate seasonal fluctuations in water level at that time.

\section{Inferred Weichselian late-glacial palaeoenvironment}

Brief summaries of the inferred regional and local vegetation are presented in Tables 2 and 3 respectively; Figs 5-7 together present the palaeovegetation data upon which these inferences are based. Taken together with the sediment lithological information, these data and the palaeovegetation inferences that they support provide a basis for inferring the character of the palaeoenvironment of the northern part of the Thracian Plain during the Weichselian late-glacial.

The onset of sedimentation at Ezero, dated to c. 15,450 cal yr вр, falls in the final millennium of the Weichselian fullglacial stage (GS-2 of the GRIP event stratigraphy of Björck et al., 1998) (Fig. 4). The regional predominance of steppe and wooded steppe vegetation at this time and during EZP-1 indicates marked, but not extreme, seasonal moisture deficiency. The co-occurrence of Juniperus cf. J. excelsa, Celtis tournefortii-type and Quercus in the woody component of the flora nonetheless indicates that the regional climate was probably more continental than it is at present. The co-occurrence of these three taxa today is limited to parts of Crimea, Turkey and Transcaucasia (Fig. 8). Much of the area of co-occurrence today experiences more severe seasonal moisture deficiency (ratio of actual to potential evapotranspiration (AET/PET) down to below 0.35) than the region surrounding the study site, as well as a larger seasonal temperature range, the coldest month mean temperature being below $-10^{\circ} \mathrm{C}$ in some areas whereas the warmest month mean mainly is between 20 and $25^{\circ} \mathrm{C}$, falling below $20^{\circ} \mathrm{C}$ only in some more mountainous areas (W. Cramer, unpublished interpolations based upon Leemans \& Cramer, 1991). The 

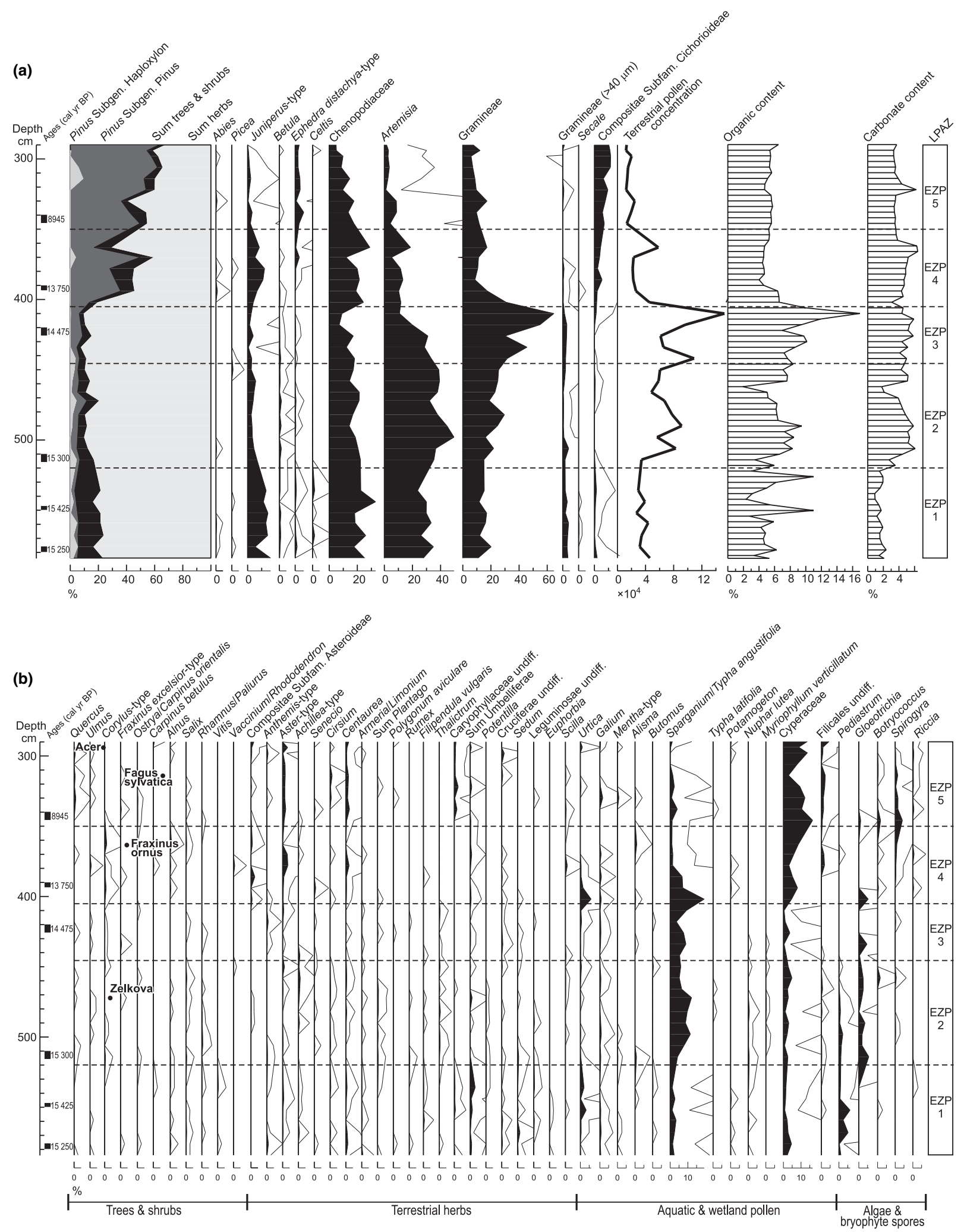

Figure 5 Pollen diagram for the EZ-2 sediment core. Pollen percentage values are plotted against depth for the lower half of the Ezero wetland core, which spans the Weichselian late-glacial. (a) More abundant terrestrial pollen taxa, total terrestrial pollen concentration, sediment organic content, and sediment carbonate content. (b) Selected terrestrial, wetland and aquatic pollen taxa present only with relatively low abundance. In each case the positions of samples from which radiocarbon age estimates were obtained, and their ages in calibrated years вр, are shown alongside the depth scale, and the local terrestrial pollen assemblage zones are indicated on the right. 


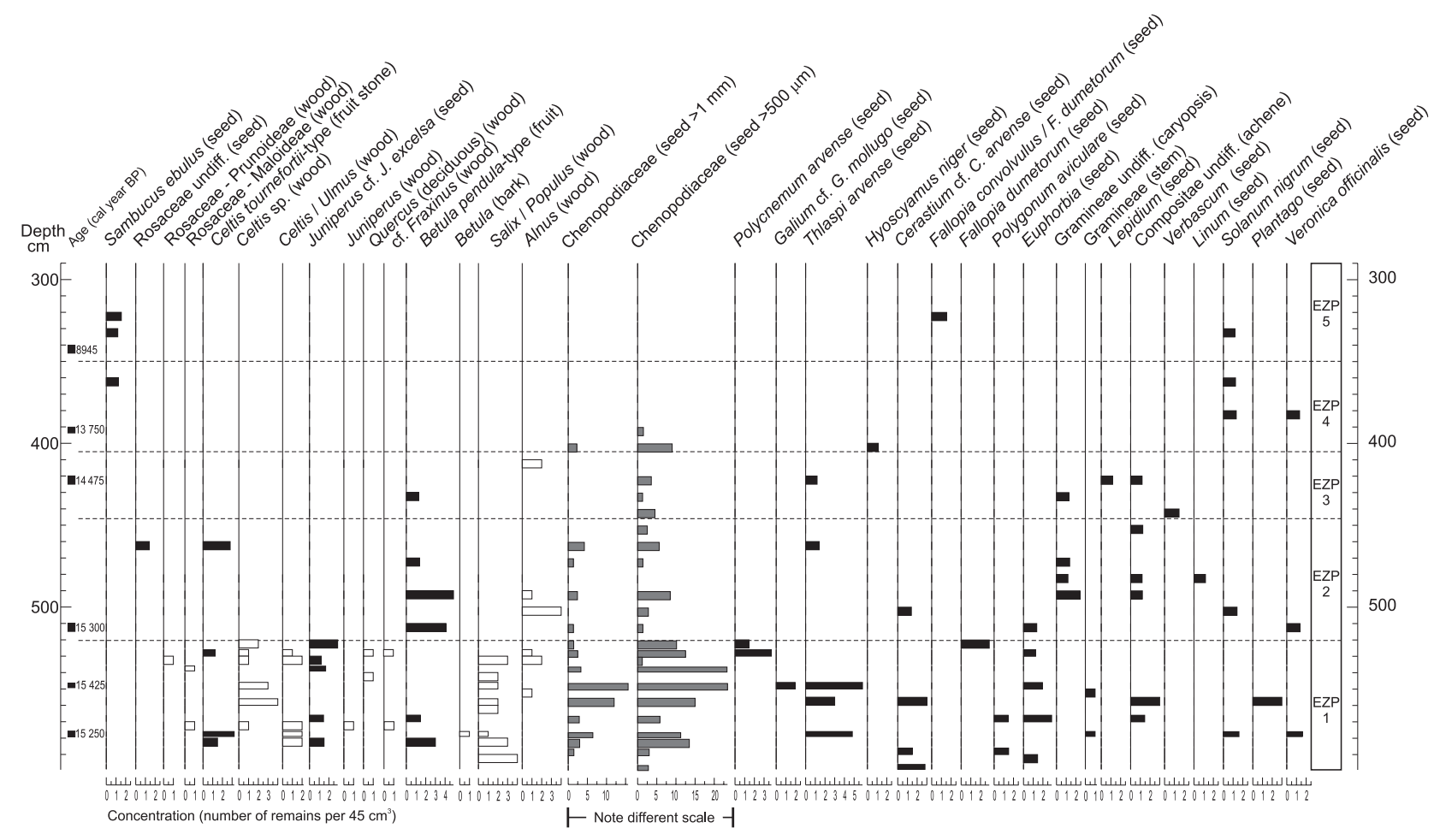

Figure 6 Terrestrial plant macrofossil diagram for the EZ-2 sediment core. Concentration values for fruits/seeds (filled bars) and identified wood fragments $(>2 \mathrm{~mm}$ ) (open bars) are plotted against depth for the lower half of the Ezero wetland core, which spans the Weichselian late-glacial. The positions of samples from which radiocarbon age estimates were obtained, and their ages in calibrated years вр, are shown alongside the depth scale, and the local terrestrial pollen assemblage zones are indicated on the right.

presence of communities of ruderal herbs (sensu Grime, 1978) around the lake shore, as well as of the mollusc S. oblonga, most probably associated with seasonally exposed marginal areas, also indicates seasonal moisture deficiency severe enough to result in fluctuations in water level in the lake. The absence of remains of characteristically Mediterranean taxa, combined with the presence of cold-tolerant taxa such as Betula, further indicates lower winter temperatures than at present in the region, Betula occurring today only where the coldest month mean temperature is below $0^{\circ} \mathrm{C}$ (B. Huntley, unpublished data). The erosion inferred from the rapidly accumulated sandy sediments probably indicates that winter temperatures were markedly lower than they are at present. These climatic inferences are broadly consistent with the palaeoclimate simulated for $12,000{ }^{14} \mathrm{C} \mathrm{yr}$ BP in this region by Kutzbach et al. (1993).

After only c. 250 years, steppe, especially of Artemisia and Gramineae, became more predominant during EZP-2, whereas both the abundance and variety of woody taxa decreased. Although this change might be taken to indicate more severe seasonal aridity than previously, the reduced abundance of Chenopodiaceae is in conflict with such an interpretation. Given that fruits of Betula are more abundant than previously, that the abundance and variety of other woody taxa are reduced, and that the pollen concentration is increased, indicating an overall increase in vegetation cover and/or productivity, it is more likely that temperatures were cooler than before. Such cooler temperatures would be unfavourable to the majority of woody taxa, but Betula tolerates cooler conditions than most other tree taxa. In the wetland itself, the finer-grained and partially organic sediments are consistent with more complete vegetation cover of the surrounding landscape, leading to reduced erosion, and the replacement of ruderal communities around the lake shore by communities of emergent aquatics probably indicates less severe seasonal water-level fluctuations than before. The latter is consistent with the shift in composition of the steppe, although whether it reflects decreased summer temperatures, and hence reduced evaporative and transpirational demand, or increased precipitation, and hence greater moisture supply, is unclear.

At c. 14,650 cal yr BP, coinciding closely with the age of onset of the Weichselian late-glacial interstadial (GI-1 in the GRIP event stratigraphy of Björck et al., 1998), marked changes in the regional vegetation indicate a further shift in environmental conditions. Although steppe continued to dominate for $c$. 500 years after this time (EZP-3), and woody taxa remained infrequent, the composition of the steppe had changed, Gramineae now predominating and Artemisia being less abundant than previously. Pollen concentration reached its peak during this interval. These changes indicate a reduced seasonal moisture deficit, allowing a shift towards more productive steppe grasslands and a reduced extent of the 


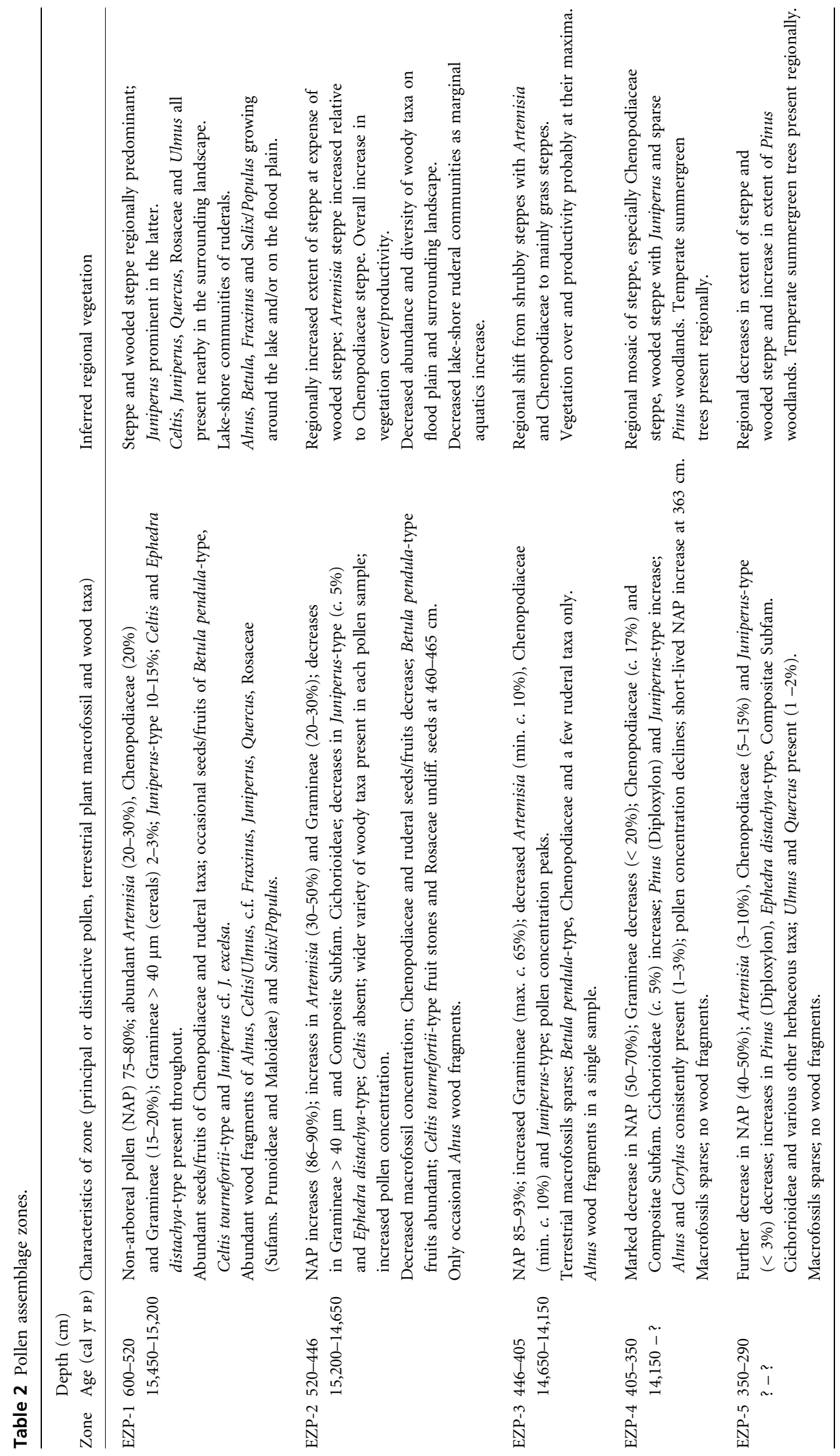




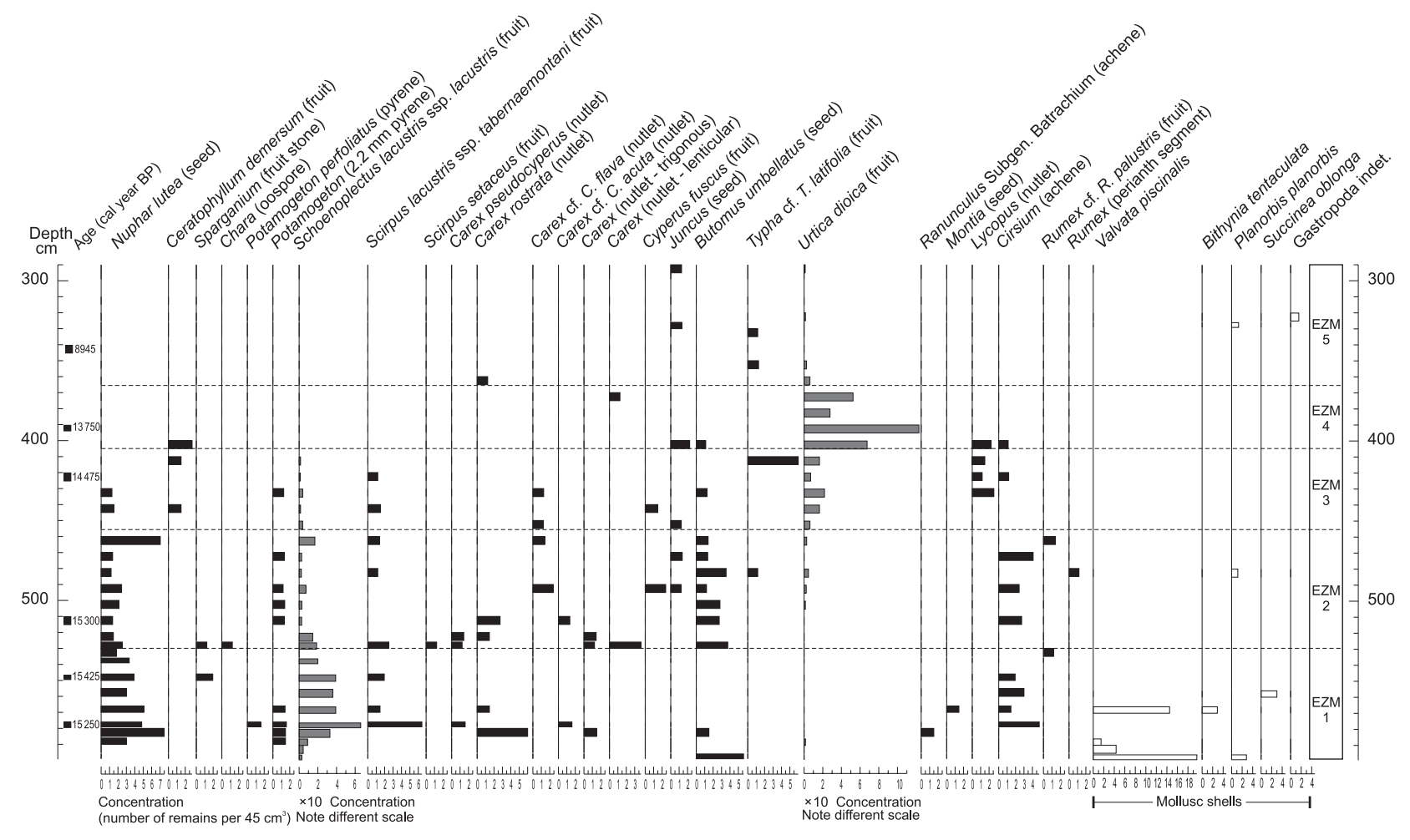

Figure 7 Aquatic and wetland plant macrofossil and mollusc diagram for the EZ-2 sediment core. Concentration values for fruits/ seeds/oospores (filled bars) and mollusc shells (open bars) are plotted against depth for the lower half of the Ezero wetland core, which spans the Weichselian late-glacial. The positions of samples from which radiocarbon age estimates were obtained, and their ages in calibrated years вр, are shown alongside the depth scale, and the local aquatic/wetland macrofossil assemblage zones are indicated on the right.

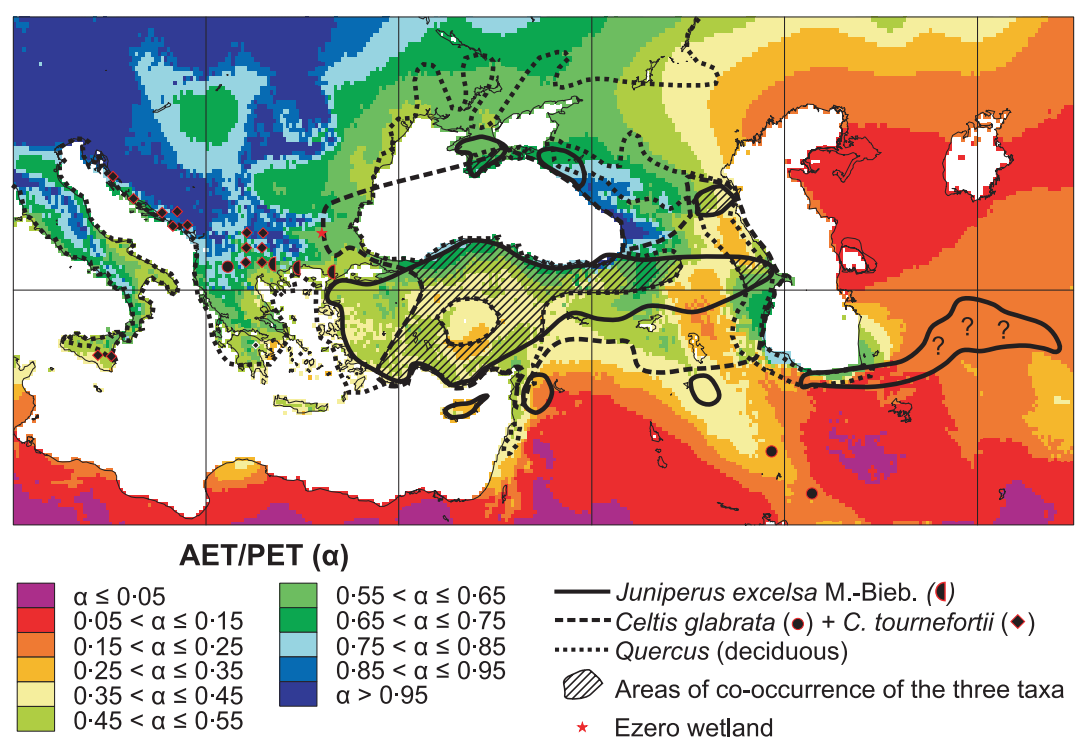

Figure 8 Distributions of three woody plant taxa in relation to moisture availability. The present (1931-60) ratio of actual to potential evapotranspiration (AET/PET, Priestley-Taylor's $\alpha$ ) was estimated from climatic data compiled by Leemans \& Cramer (1991), and interpolated to a 10 ' longitude $\times$ latitude grid (W. Cramer, unpublished data), using the 'bucket' model of Cramer \& Prentice (1988). Distributions are shown for three woody plant taxa found as macrofossils in the Weichselian late-glacial sediments at Ezero: Juniperus excelsa M.-Bieb.; Celtis glabrata plus C. tournefortii ( $\equiv$ C. tournefortii-type); and Quercus (excluding Q. ilex, Q. coccifera and other evergreen species of the Mediterranean basin). Distributions have been redrawn from Meusel et al. (1965), Browicz \& Zieliński (1977), Farjon (1992) and Jalas \& Suominen (1973, 1976). 
The 'oriental' component of the Balkan flora

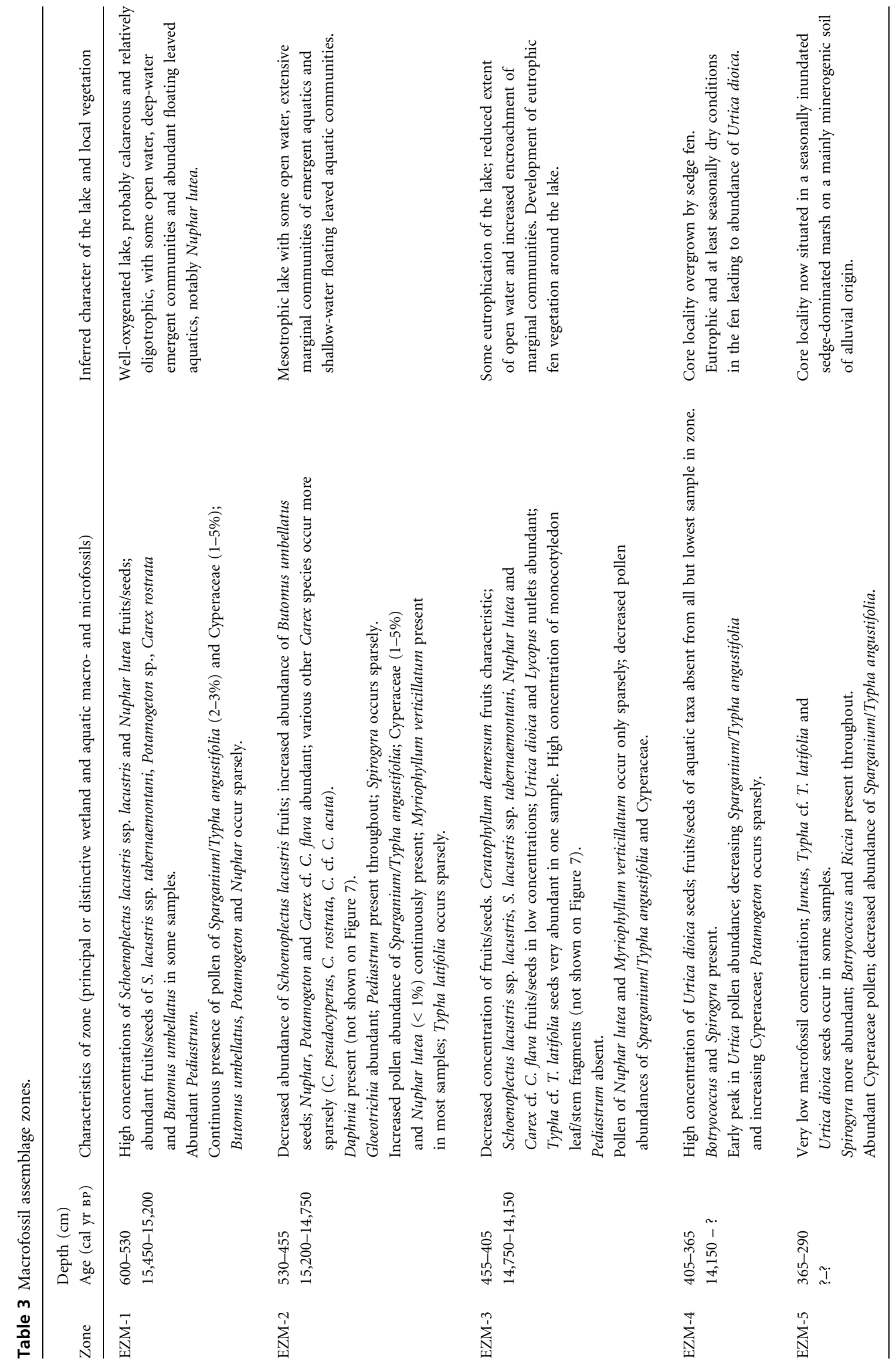


shrubby steppe that previously dominated (Zohary, 1973). The sediments deposited in the Ezero wetland during this interval were more organic and peaty in character than before. Although this may simply reflect local hydroseral succession, evidence of which is seen in the aquatic and wetland macrofossil record, these hydroseral changes themselves are nonetheless indicative of relatively stable water levels. They are thus consistent with the reduced seasonal moisture deficiency inferred from the change in steppe composition. Inferring the nature of any temperature changes at the transition to this interval is difficult because of a lack of clear evidence upon which to base such inferences.

The next change in the regional vegetation, at c. 14,150 cal yr вр, falls close to the age of 14,050 for the onset of GI-1d in the GRIP chronology (Björck et al., 1998); GI-1d is generally considered to correspond to the Older Dryas. The inferred shift in the regional vegetation around the Ezero wetland at this time to a mosaic of steppe, wooded steppe and sparse Pinus woodlands, with temperate summergreen trees present at least regionally, indicates complex environmental changes at the transition from EZP-3 to EZP-4. The shift in composition of the steppe, with increased abundance of Chenopodiaceae and markedly reduced abundance of Gramineae, implies a more marked seasonal moisture deficit in summer than previously, as well as perhaps a more continental climatic regime. The increased abundance of woody taxa appears to conflict with this inference, however, although this may be indicative principally of increased temperatures. The change in character of the sediments in the basin that occurs just after the initial shift in character of the regional vegetation, however, provides an important clue as to what may have been happening, the onset of deposition of clay-silt sediments being interpreted as evidence of seasonal flooding by the adjacent river. Such seasonal floods may either be spring events, associated with the melting of snow in the mountains around the headwaters of the river in the eastern part of the Sredna Gora, or reflect extreme precipitation events that, according to their origin, may occur in various seasons. Given the evidence of summer drought, it is more likely that the floods occurred between autumn and spring. Furthermore, the coincidence between the change in character of the sediments, a marked decrease in pollen concentration, a marked increase in the abundance of Pinus pollen, and the consistent presence of pollen of temperate summergreen trees, probably indicates that the floodwaters carried pollen from more distant woodland sources to the basin. The relative abundance of Pinus pollen in these sediments may indicate that the floods were spring events, Pinus spp. shedding their pollen in this season. Whether these were meltwater or extreme precipitation events, however, cannot be resolved on the basis of the available evidence.

Although we are unable to assign an age to the final change in regional vegetation recorded at Ezero, the transition from EZP-4 to EZP-5, it is tempting to speculate that it corresponded to the onset of the Allerød (GI-1c in the GRIP event stratigraphy of Björck et al., 1998, i.e. 13,900 yr BP in the GRIP chronology), the accumulation of the alluvial sediments probably being more rapid than that in the underlying more organic unit. The inferred decrease in the extent of steppe and wooded steppe and the increase in the extent of woodlands would indicate a decrease in seasonal moisture deficit, as would the decrease in the relative abundance of Artemisia and Chenopodiaceae, and the increase in Gramineae, in the remaining areas of steppe.

\section{DISCUSSION}

There are very few previous published records from the southern Balkans of plant macrofossils from late Weichselian and/or Weichselian late-glacial sediments with which to compare our results (Tzedakis, 2004). At Franchthi Cave, in southern Greece (Fig. 1), however, Hansen (1991) recorded Celtis tournefortii-type fruit stones, as well as Juniperus charcoal, from late Weichselian and Weichselian late-glacial sediments, indicating that at least one woody member of the oriental element also reached that area during this period. Celtis pollen and/or macrofossils also have been recorded from a number of Palaeolithic archaeological sites dating from the Weichselian late-glacial in Turkey (Martinoli, 2001; EmeryBarbier \& Thiébault, 2005) and Syria (Matsutani, 1987; Hillman et al., 1989), indicating the wider distribution of members of the genus in south-west Asia at this time. Furthermore, the principal Celtis macrofossils recorded by Martinoli (2001) from the locality that she studied in Anatolia were fruit stones of $C$. tournefortii-type. At some of these localities, macrofossils of a variety of other woody taxa found today in the wooded steppe vegetation of Anatolia have been recorded: Emery-Barbier \& Thiébault (2005), for example, recorded Juniperus/Cupressus, Prunus cf. P. dulcis, Quercus (deciduous), Rosaceae Subfam. Maloideae and Sorbus/Crataegus from Weichselian late-glacial layers in the Öküzini cave, south-west Anatolia. In addition, macrofossil studies at a number of sites in Turkey and the Middle East have provided evidence of the presence of a diverse arboreal flora during this interval. At Tell Abu Hureyra, Syria, for example, Hillman et al. (1989) found charcoal evidence of a range of woody taxa, including some characteristic of riparian habitats, such as Fraxinus, Salix/Populus and Tamarix, and others typical of the sclerophyll woodlands and scrub of the Mediterranean region today, such as Anacardiaceae, Pistacia, Quercus (sclerophyllous), Rhamnus/Phillyrea and Olea. Our macrofossil record from the Ezero wetland similarly includes additional woody taxa that may represent species found today in wooded steppe vegetation (Rosaceae Subfam. Maloideae, Rosaceae Subfam. Prunoideae) and in riparian habitats (Alnus, Fraxinus, Salix/ Populus).

The frequent occurrence of a diverse range of woody taxa in these macrofossil records contrasts with the overwhelming predominance of herbaceous taxa in pollen records from the region over the same period (van Zeist \& Bottema, 1977; Bottema, 1978, 1979; Yasuda et al., 2000; Tzedakis et al., 2002, 2004; Wick et al., 2003). These records generally have been 
interpreted as indicating the predominance of steppe vegetation, and a strongly continental climate, in the region during the late Weichselian and Weichselian late-glacial, although with evidence of the onset of expansion of deciduous Quercus in the Levant during the Weichselian late-glacial interstadial (Wright \& Thorpe, 2005). Tzedakis et al. (2002, 2004) interpreted the numerous pollen records from north-east Greece as indicating the ubiquitous predominance of Artemisia-Chenopodiaceae steppes in lowland areas during the late Weichselian and Weichselian late-glacial, and suggested that trees were confined to the mountains at this time. Willis (1992a) arrived at a similar conclusion for north-west Greece, inferring that, although small numbers of Quercus and Pinus trees were present in the lowlands, steppe predominated. Although she inferred, from the composition of the early Holocene vegetation recorded at a montane site (Willis, 1992b), that steppe vegetation also dominated at higher elevations, the diversity of tree taxa recorded there was greater than that in the lowlands, leading her to conclude that a variety of trees, including temperate summergreen taxa such as Tilia and Ulmus, were present in the mountains throughout the Weichselian (Willis, 1992c). Pollen records from the Rila and Pirin mountains of south-west Bulgaria (Fig. 1) reveal a similar picture of predominantly montane steppe vegetation during the Weichselian late-glacial, with the few trees that were present, mostly during the Weichselian late-glacial interstadial, being principally Pinus and other needle-leaved evergreens, with only sparse evidence of temperate summergreen trees (Bozilova \& Tonkov, 2000; Atanassova \& Stefanova, 2003; Stefanova \& Ammann, 2003).

Such apparently conflicting evidence of macrofossils and pollen, with respect to the distribution and occurrence of woody taxa, is mirrored in a number of studies from other regions (Kullman, 1998a,b,c; Willis et al., 2000; Willis \& van Andel, 2004). In the case of the late Weichselian and Weichselian late-glacial periods in the southern Balkans, the macrofossil evidence from the Ezero wetland demonstrates that a range of woody taxa was present in the lowlands, notwithstanding the predominance of herbaceous and/or shrubby taxa characteristic of steppe habitats in the pollen records. The nature of these taxa differed, however, from that of those inferred to have been present during the same interval in montane areas (Willis, 1992b). The woody element of the lowland vegetation comprised relatively drought-tolerant taxa typical today of woody steppe vegetation (e.g. Celtis tournefortii-type, Juniperus cf. J. excelsa, Rosaceae Subfams. Maloideae and Prunoideae), including members of the oriental element of the present Balkan flora, as well as riparian taxa (e.g. Alnus, Fraxinus, Salix/Populus). In the mountains, in contrast, the woody taxa present were mainly evergreen needle-leaved trees (Bozilova \& Tonkov, 2000; Atanassova \& Stefanova, 2003; Stefanova \& Ammann, 2003), as well as some temperate summergreen trees (Willis, 1992b). It is likely that, both in lowland and montane areas, the trees occupied spatially restricted patches of favourable habitats in a landscape that was dominated by the herbaceous and/or shrubby steppes reflected in the pollen records. It also is likely, at least in the lowlands, that the vegetation of these favourable habitats was relatively open wooded steppe, rather than closed forest patches, although the riparian taxa may have formed denser stands of gallery forests.

The palaeobotanical evidence from the Ezero wetland thus provides for the first time evidence in support of Turrill's (1929) hypothesis that the oriental element in the present Balkan flora at least in part could have reached the southern Balkans via the Thracian Plain during times of lowered Mediterranean sea-level, such as occurred during the glacial stages of the Quaternary. Macrofossil evidence has shown that the generally steppe-dominated landscape of the Thracian Plain during the late Weichselian and Weichselian late-glacial supported patches of wooded steppe. Furthermore, macrofossils of woody members of the oriental floristic element also have been found in the sediments from that interval, notably Celtis tournefortii-type and Juniperus cf. J. excelsa, and several of the other macrofossil taxa found may represent other woody members of this element (e.g. Rosaceae Subfam. Maloideae includes Pyrus elaeagrifolia and Crataegus laciniata). Although this does not in any sense 'prove' that the oriental element of the Balkan flora even in part entered the region during the Weichselian by migration from Turkey across the Thracian Plain, it does show that this was possible, and that some members of the element were present on the Thracian Plain during that time. It hence renders the hypothesis that such taxa are of Tertiary relict origin at least not universally necessary. Further careful studies of macrofossil records, not only from the Balkans but also from other parts of southern Europe, are required to assess the extent to which other taxa with biogeographical affinities to south-west Asia may have expanded their ranges into southern Europe during the Weichselian, or earlier Quaternary glacial stages. Evidence from Lago Grande di Monticchio, in southern Italy, however, indicates that wooded steppe vegetation may have been widespread in the Mediterranean region during many of the interstadials of the last glacial stage (Allen et al., 1999, 2000); taxa associated with this habitat thus had repeated opportunities to expand widely in the region. It may be more realistic to re-evaluate many, if not all, of these taxa as 'glacial relicts', persisting in southern Europe today in 'Holocene refuges'. Whether or not they had a similar relict distribution in southern Europe during the last or previous interglacials is more challenging to determine. Macrofossil studies of suitable interglacial deposits will offer one potential source of evidence, and genetic studies of the fragmented extant populations of such species might in future provide a basis for estimating the period during which they have been isolated. Whatever the history of individual taxa, however, it is clear from the record obtained from the Ezero wetland that the paradigm of extensive treeless steppe vegetation in the lowlands of southern Europe and around the Mediterranean during the late Weichselian and the Weichselian late-glacial can no longer be sustained. Only by taking into account all types of palaeobotanical evidence can a more complete picture be 
obtained of the complexity of the past vegetation cover in this and other regions, and only with such a more complete picture can we address key questions in historical biogeography.

\section{ACKNOWLEDGEMENTS}

This research was funded by the European Commission through a Marie Curie Postdoctoral Fellowship held by E.K.M. (MEIF-CT-2003-5005001). Financial support for the field work was provided by the British Academy. The authors are grateful to Angelica Feurdean, Konstantin Kremenetski and an anonymous referee for their helpful and constructive criticisms of an earlier version of the paper. This is MTAMTM Paleo Contribution No. 62.

\section{REFERENCES}

Adams, R.P. (1999) Systematics of multi-seeded eastern hemisphere Juniperus based on leaf essential oils and RAPD DNA fingerprinting. Biochemical Systematics and Ecology, 27, 709-725.

Adams, R.P. (2001) Geographic variation in leaf essential oils and RAPDs of Juniperus polycarpos K. Koch in central Asia. Biochemical Systematics and Ecology, 29, 609-619.

Adams, R.P., Morris, J.A., Pandey, R.N. \& Schwarzbach, A.E. (2005) Cryptic speciation between Juniperus deltoides and Juniperus oxycedrus (Cupressaceae) in the Mediterranean. Biochemical Systematics and Ecology, 33, 771-787.

Allen, J.R.M., Brandt, U., Brauer, A., Hubberten, H., Huntley, B., Keller, J., Kraml, M., Mackensen, A., Mingram, J., Negendank, J.F.W., Nowaczyk, N.R., Oberhänsli, H., Watts, W.A., Wulf, S. \& Zolitschka, B. (1999) Rapid environmental changes in southern Europe during the last glacial period. Nature, 400, 740-743.

Allen, J.R.M., Watts, W.A. \& Huntley, B. (2000) Weichselian palynostratigraphy, palaeovegetation and palaeoenvironment: the record from Lago Grande di Monticchio, southern Italy. Quaternary International, 73/74, 91-110.

van Andel, T.H. \& Tzedakis, P.C. (1996) Palaeolithic landscapes of Europe and Environs, 150,000-25,000 years ago: an overview. Quaternary Science Reviews, 15, 481-500.

Anderberg, A.L. (1994) Atlas of seeds and small fruits of Northwest-European plant species with morphological descriptions. Part 4: Resedaceae-Umbelliferae. Swedish Museum of Natural History, Risbergs Tryckeri AB, Uddevalla.

Angelova, D., Nenov, T. \& Spiridonov, H. (1993) Rechnite terasi na reka Maritsa i kvaternernoto razvitie na Gornotrakiiskata nizina (The river terraces of the Maritza river in the Quaternary: Development of High Thracian lowland; in Bulgarian). Review of the Bulgarian Geological Society, 54, 41-59.

Atanassova, J. (2005) Palaeoecological setting of the western Black Sea area during the last 15000 years. Holocene, 15, 576-584.

Atanassova, J. \& Marinova, E. (2005) Contribution to the flora of disappearing wetlands in the Toundzha Hilly Country (SE Bulgaria). Phytologia Balcanica, 11, 139-144.
Atanassova, J. \& Stefanova, I. (2003) Late-glacial vegetational history of Lake Kremensko-5 in the northern Pirin Mountains, southwestern Bulgaria. Vegetation History and Archaeobotany, 12, 1-6.

Beijerinck, W. (1976) Zadenatlas der Nederlandse Flora, Ten Behoeve van de Botanie, Palaeontologie, Bodemcultuur en Warenkennis. Backhuys and Meesters, Amsterdam.

Bennett, K.D. (1992) PSIMPOLL: a quickBASIC program that generates PostScript page description files of pollen diagrams. INQUA Commission for the Study of the Holocene: Working Group on Data Handling Methods Newsletter, 8, 1112.

Bennett, K.D. (1996) Determination of the number of zones in a biostratigraphical sequence. New Phytologist, 132, 155-170.

Bennett, K.D., Tzedakis, P.C. \& Willis, K.J. (1991) Quaternary refugia of north European trees. Journal of Biogeography, 18, 103-115.

Berggren, G. (1969) Atlas of seeds and small fruits of NorthwestEuropean plant species with morphological descriptions. Part 2: Cyperaceae. Swedish Natural Science Research Council, Berlingska Bogtryckeriet, Lund.

Berggren, G. (1981) Atlas of seeds and small fruits of NorthwestEuropean plant species with morphological descriptions. Part 3: Salicaceae-Cruciferae. Swedish Museum of Natural History, Berlings, Arlöv.

Beug, H.J. (2004) Leitfaden der Pollenbestimmung für Mitteleuropa und angrendzende Gebiete. Verlag Dr Friedrich Pfeil, München.

Birks, H.J.B. \& Gordon, A.D. (1985) Numerical methods in Quaternary pollen analysis. Academic Press, London.

Björck, S., Walker, M.J.C., Cwynar, L.C., Johnsen, S., Knudsen, K.-L., Lowe, J.J., Wohlfarth, B. \& INTIMATE Members (1998) An event stratigraphy for the Last Termination in the North Atlantic region based on the Greenland ice-core record: a proposal by the INTIMATE group. Journal of Quaternary Science, 13, 283-292.

Bondev, I. (1991) Rastitelnostta v Bulgaria (The vegetation map of Bulgaria with explanatory text; in Bulgarian). St. Kliment Ohridski University Press, Sofia.

Bottema, S. (1978) The late glacial in the eastern Mediterranean and the Near East. The vegetation of the Near and Middle East since the last ice age (ed. by W.C. Brice), pp. 15-28. Academic Press, London.

Bottema, S. (1979) Pollen investigations in Thessaly (Greece). Palaeohistoria, 21, 19-40.

Bozilova, E.D. \& Tonkov, S.B. (2000) Pollen from Lake Sedmo Rilsko reveals southeast European postglacial vegetation in the highest mountain area of the Balkans. New Phytologist, 148, 315-325.

Bozilova, E., Filipova, M., Filipovich, L. \& Tonkov, S. (1996) Bulgaria. Palaeoecological events during the last 15,000 years: regional syntheses of palaeoecological studies of lakes and mires in Europe (ed. by B.E. Berglund, H.J.B. Birks, M. RalskaJasiewiczowa and H.E. Wright), pp. 701-728. Wiley, Chichester. 
Brauer, A., Allen, J.R.M., Mingram, J., Dulski, P., Wulf, S. \& Huntley, B. (2007) Evidence for last interglacial chronology and environmental change from Southern Europe. Proceedings of the National Academy of Sciences USA, 104, 450-455.

Brewer, S., Cheddadi, R., de Beaulieu, J.L. \& Reille, M. (2002) The spread of deciduous Quercus throughout Europe since the last glacial period. Forest Ecology and Management, 156, 27-48.

Browicz, K. \& Zieliński, J. (1977) Two new taxa within the Ulmaceae family for the flora of Bulgaria and their geographical distribution. Fragmenta Flora Geobotanica, 23, 141-150.

Browicz, K. \& Zieliński, J. (1982). Celtis L. Flora of Turkey (ed. by P.H. Davis), pp. 649-652. Edinburgh University Press, Edinburgh.

Brown, A.G. (1997) Alluvial geoarchaeology: floodplain archaeology and environmental change. Cambridge University Press, Cambridge.

Cramer, W. \& Prentice, I.C. (1988) Simulation of soil moisture deficits on a European scale. Norsk Geografisk Tidskrift, 42, 149-151.

Dennell, R. (1978) Early farming in South Bulgaria from the VI to the III millennia B.C. British Archaeological Reports, International Series (Supplementary) No.45. Archaeopress, Oxford.

Emery-Barbier, A. \& Thiébault, S. (2005) Preliminary conclusions on the Late Glacial vegetation in south-west Anatolia (Turkey): the complementary nature of palynological and anthracological approaches. Journal of Archaeological Science, 32, 1232-1251.

Fairbanks, R.G. (1989) A 17,000-year glacio-eustatic sea level record: Influence of glacial melting rates on the Younger Dryas event and deep-ocean circulation. Nature, 342, 637642.

Farjon, A. (1992) The taxonomy of multiseed junipers (Juniperus sect. Sabina) in southwest Asia and east Africa (Taxonomic notes on Cupressaceae I). Edinburgh Journal of Botany, 49, 251-283.

Georgiev, G.I., Merpert, N.I., Katincharov, P.V. \& Dimitrov, D. (eds) (1979) Ezero: ranobronzovoto selishte. BAN, Sofia.

Greguss, P. (1972) Xylotomy of living conifers. Akademiai Kiadó, Budapest.

Grime, J.P. (1978) Plant strategies and vegetation processes. John Wiley \& Sons, New York.

Grivet, D. \& Petit, R.E.J. (2003) Chloroplast DNA phylogeography of the hornbeam in Europe: evidence for a bottleneck at the outset of postglacial colonization. Conservation Genetics, 4, 47-56.

Hansen, J.M. (1991) The palaeoethnobotany of Franchthi Cave. Indiana University Press, Bloomington.

Heiri, O., Lotter, A.F. \& Lemcke, G. (2001) Loss on ignition as a method for estimating organic and carbonate content in sediments: reproducibility and comparability of results. Journal of Paleolimnology, 25, 101-110.

Heuertz, M., Fineschi, S., Anzidei, M., Pastorelli, R., Salvini, D., Paule, L., Frascaria-Lacoste, N., Hardy, O.J., Vekemans,
X. \& Vendramin, G.G. (2004) Chloroplast DNA variation and postglacial recolonization of common ash (Fraxinus excelsior L.) in Europe. Molecular Ecology, 13, 3437-3452.

Hillman, G.C., Colledge, S.M. \& Harris, D.R. (1989) Plantfood economy during the Epipalaeolithic period at Tell Abu Hureyra, Syria: dietary diversity, seasonality and modes of exploitation. Foraging and farming, the evolution of plant exploitation (ed. by D.R. Harris and G.C. Hillman), pp. 240 268. Unwin Hyman Ltd., London.

Huntley, B., Alfano, M.J., Allen, J.R.M., Pollard, D., Tzedakis, P.C., de Beaulieu, J.-L., Grüger, E. \& Watts, B. (2003) European vegetation during marine oxygen isotope Stage 3. Quaternary Research, 59, 195-212.

Jalas, J. \& Suominen, J. (eds) (1973) Atlas Florae Europaeae. 2. Gymnospermae (Pinaceae to Ephedraceae). Societas Biologica Fennica Vanamo, Helsinki.

Jalas, J. \& Suominen, J. (eds) (1976) Atlas Florae Europaeae 3. Salicaceae to Balanophoraceae. Societas Biologica Fennica Vanamo, Helsinki.

Jalas, J. \& Suominen, J. (eds) (1983) Atlas Florae Europaeae 6. Caryophyllaceae (Alsinoideae and Paronychioideae). Societas Biologica Fennica Vanamo, Helsinki.

Katz, N.J., Katz, S.V. \& Kipiani, M.G. (1965) Atlas and keys of fruits and seeds occurring in the Quaternary deposits of the U.S.S.R. (Partial English translation by J.C. Ritchie). Academy of Sciences of the U.S.S.R., Commission for Investigations of the Quaternary Period, Nauka, Moscow.

Kerney, M.P., Cameron, R.A.D. \& Riley, G. (1979) A field guide to the land snails of Britain and North-west Europe. Collins, London.

Kerney, M.P., Cameron, R.A.D. \& Jungbluth, J.H. (1983) Die Landschnecken Nord- und Mitteleuropas. Parey Press, Hamburg.

Kirilova, M. (1985) Suvremenni landshafti v raiona na SMEK "Maritsa-Iztok" I problemi na tiahnata rekultivatsia. Hons. Thesis. Sofia University, Department of Landscape Studies and Preservation of the Environment.

Kozuharov, S. (1992) Opredelitel na viscite rastenija $v$ Blgariaja (Vascular flora of Bulgaria). Nauka I Izkustvo, Sofia.

Kullman, L. (1998a) Non-analogous tree flora in the Scandes Mountains, Sweden, during the early Holocene - macrofossil evidence of rapid geographic spread and response to palaeoclimate. Boreas, 27, 153-161.

Kullman, L. (1998b) The occurrence of thermophilous trees in the Scandes Mountains during the early Holocene: evidence for a diverse tree flora from macroscopic remains. Journal of Ecology, 86, 421-428.

Kullman, L. (1998c) Palaeoecological, biogeographical and palaeoclimatological implications of early Holocene immigration of Larix sibirica Ledeb. into the Scandes mountains, Sweden. Global Ecology and Biogeography Letters, 7, 181-188.

Kutzbach, J.E., Guetter, P.J., Behling, P.J. \& Selin, R. (1993) Simulated climatic changes: results of the COHMAP climate-model experiments. Global climates since the Last Glacial Maximum (ed. by H.E. Wright Jr, J.E. Kutzbach, T. Webb III, W.F. Ruddiman, F.A. Street-Perrott and 
P.J. Bartlein), pp. 24-93. University of Minnesota Press, Minneapolis, MN.

Leemans, R. \& Cramer, W. (1991) The IIASA database for mean monthly values of temperature, precipitation and cloudiness of a global terrestrial grid. RR-91-18. Research Report. International Institute for Applied Systems Analysis (IIASA), Laxenburg, Austria.

Martinoli, D. (2001) Les macrorestes botaniques de la grotte d'Öküzini. Öküzini: final Palaeolithic evolution in southwest Anatolia (in French; ed. by I. Yalcinkaya, M. Otte, J. Kozlowski and O. Bar-Yosef), pp. 91-94. ERAUL, Liége.

Matsutani, A. (1987) Plant remains from the 1984 excavations at Douara Cave. Paleolithic site of Douara Cave and paleogeography of Palmyra basin in Syria. Part IV: 1984 Excavation (ed. by T. Akazawa and Y. Sakaguchi), Chapter 7, Bulletin No. 29. The University Museum, The University of Tokyo, Tokyo.

McNeill, J. (1963) Taxonomic studies in the Alsinoideae. II. A revision of the species in the Orient. Notes from the Royal Botanic Garden, Edinburgh, 24, 241-404.

Meusel, H., Jäger, E. \& Weinert, E. (1965) Vergleichende Chorologie der Zentraleuropäischen Flora. Gustav Fischer Verlag, Jena.

Moore, P.D., Webb, J.A. \& Collinson, M.E. (1992) Pollen analysis, 2nd edn. Blackwell Scientific Publications, Oxford.

Nam, K. (1995) Niakoi aspekti na antropogennite izmenenia na landshaftite v obhvata na vanshno nasipishe "Mednikarovo" i sasedni teritorii. Godishnik na Sofiiskia Universitet "Sv. Kliment Ohridski", Geologo-geografiski fakultet, 87, 235249.

Nedialkov, N. (1985) Geolozhkiat stroezh na Iztochnomarishkia Basein I svlachishtinia fenomen. $\mathrm{PhD}$ thesis, Bulgarian Academy of Science, Sofia.

Palamarev, E. (2002) Vegetation. Geography of Bulgaria (ed. by I. Kopralev), pp. 317-321. For Com Publishers, Sofia.

Palme, A.E. \& Vendramin, G.G. (2002) Chloroplast DNA variation, postglacial recolonization and hybridization in hazel, Corylus avellana. Molecular Ecology, 11, 1769-1780.

Petit, R.J., Csaikl, U.M., Bordacs, S., Burg, K., Coart, E., Cottrell, J., van Dam, B., Deans, J.D., Dumolin-Lapegue, S., Fineschi, S., Finkeldey, R., Gillies, A., Glaz, I., Goicoechea, P.G., Jensen, J.S., König, A.O., Lowe, A.J., Madsen, S.F., Mátyás, G., Munro, R.C., Olalde, M., Pemonge, M.-H., Popescu, F., Slade, D., Tabbener, H., Taurchini, D., de Vries, S.G.M., Ziegenhagen, B. \& Kremer, A. (2002) Chloroplast DNA variation in European white oaks: phylogeography and patterns of diversity based on data from over 2600 populations. Forest Ecology and Management, 156, 5-26.

Petit, R.J., Aguinagalde, I., de Beaulieu, J.-L., Bittkau, C., Brewer, S., Cheddadi, R., Ennos, R., Fineschi, S., Grivet, D., Lascoux, M., Mohanty, A., Muller-Starck, G., DemesureMusch, B., Palme, A., Martin, J.P., Rendell, S. \& Vendramin, G.G. (2003) Glacial refugia: hotspots but not melting pots of genetic diversity. Science, 300, 1563-1565.

Polunin, O. (1980) Flowers of Greece and the Balkans. Oxford University Press, Oxford.
Ribera, I. \& Blasco-Zumeta, J. (1998) Biogeographical links between steppe insects in the Monegros region (Aragon, NE Spain), the eastern Mediterranean, and central Asia. Journal of Biogeography, 25, 969-986.

Richnovszky, A. \& Pintér, L. (1979) A vízicsigák és kagylók kishatározója (Identification key for aquatic gastropods and bivalves; in Hungarian). Akadémiai Kiadó, Budapest.

Schermann, S. (1967) Magismeret I-II (Seed identification, Volume I-II; in Hungarian). Akadémiai Kiadó, Budapest.

Schoch, W., Pawlik, B. \& Schweingruber, F.H. (1988) Botanische makroreste: Ein atlas zur bestimmung häufig gefundener und ökologisch wichtiger pflanzensamen. Paul Haupt, Bern.

Schweingruber, F.H. (1989) Tree rings - basics and applications of dendrochronology. Kluwer Academic, Berlin.

Stefanova, I. \& Ammann, B. (2003) Lateglacial and Holocene vegetation belts in the Pirin Mountains (southwestern Bulgaria). Holocene, 13, 97-107.

Stockmarr, J. (1971) Tablets with spores used in absolute pollen analysis. Pollen et Spores, 13, 614-621.

Stuiver, M., Reimer, P.J., Bard, E., Beck, J.W., Burr, G.S., Hughen, K.A., Kromer, B., McCormac, G., van der Plicht, J. \& Spurk, M. (1998) INTCAL98 Radiocarbon age calibration, 24,000-0 cal BP. Radiocarbon, 40, 1041-1083.

Turrill, W.B. (1929) The plant life of the Balkan Penninsula: $a$ phytogeographical study. Clarendon Press, Oxford.

Tutin, T.G., Heywood, V.H., Burges, N.A., Valentine, D.H., Walters, S.M. \& Webb, D.A. (eds) (1964) Flora Europaea, Vol. 1. Lycopodiaceae to Platanaceae. Cambridge University Press, Cambridge.

Tutin, T.G., Heywood, V.H., Burges, N.A., Moore, D.M., Valentine, D.H., Walters, S.M. \& Webb, D.A. (eds) (1968) Flora Europaea, Vol. 2. Rosaceae to Umbelliferae. Cambridge University Press, Cambridge.

Tutin, T.G., Heywood, V.H., Burges, N.A., Moore, D.M., Valentine, D.H., Walters, S.M. \& Webb, D.A. (eds) (1972) Flora Europaea, Vol. 3. Diapensiaceae to Myoporaceae. Cambridge University Press, Cambridge.

Tutin, T.G., Heywood, V.H., Burges, N.A., Moore, D.M., Valentine, D.H., Walters, S.M. \& Webb, D.A. (eds) (1976) Flora Europaea, Vol. 4. Plantaginaceae to Compositae (and Rubiaceae). Cambridge University Press, Cambridge.

Tutin, T.G., Heywood, V.H., Burges, N.A., Moore, D.M., Valentine, D.H., Walters, S.M. \& Webb, D.A. (eds) (1980) Flora Europaea, Vol. 5. Alismataceae to Orchidaceae (Monocotyledones). Cambridge University Press, Cambridge.

Tutin, T.G., Burges, N.A., Chater, A.O., Edmondson, J.R., Heywood, V.H., Moore, D.M., Valentine, D.H., Walters, S.M. \& Webb, D.A. (eds) (1993) Flora Europaea, Vol. 1. Psilotaceae to Platanaceae, 2nd edn. Cambridge University Press, Cambridge.

Tzedakis, P.C. (2004) The Balkans as prime glacial refugial territory of European temperate trees. Balkan biodiversity: pattern and process in the European hotspot (ed. by H.I. Griffiths, B. Krystufek and J.M. Reed), pp. 49-68. Kluwer, Dordrecht. 
Tzedakis, P.C., Lawson, I.T., Frogley, M.R., Hewitt, G.M. \& Preece, R.C. (2002) Buffered tree population changes in a Quaternary refugium: evolutionary implications. Science, 297, 2044-2047.

Tzedakis, P.C., Frogley, M.R., Lawson, I.T., Preece, R.C., Cacho, I. \& de Abreu, L. (2004) Ecological thresholds and patterns of millennial-scale climate variability: the response of vegetation in Greece during the last glacial period. Geology, 32, 109-112.

Velev, S. (2002) Climate. Geography of Bulgaria (ed. by I. Kopralev), pp. 155-157. For Com Publishers, Sofia.

Vendramin, G.G., Degen, B., Petit, R.J., Anzidei, M., Madaghiele, A. \& Ziegenhagen, B. (1999) High level of variation at Abies alba chloroplast microsatellite loci in Europe. Molecular Ecology, 8, 1117-1126.

Walker, M. (2005) Quaternary dating methods. John Wiley \& Sons Ltd, Chichester.

Wick, L., Lemcke, G. \& Sturm, M. (2003) Evidence of Lateglacial and Holocene climatic change and human impact in eastern Anatolia: high-resolution pollen, charcoal, isotopic and geochemical records from the laminated sediments of Lake Van, Turkey. The Holocene, 13, 665-675.

Willis, K.J. (1992a) The late Quaternary vegetational history of northwest Greece. I. Lake Gramousti. New Phytologist, 121, 101-117.

Willis, K.J. (1992b) The late Quaternary vegetational history of northwest Greece. II. Rezina Marsh. New Phytologist, 121, 119-138.

Willis, K.J. (1992c) The late Quaternary vegetational history of northwest Greece. III. A comparative study of two contrasting sites. New Phytologist, 121, 139-155.

Willis, K.J. \& van Andel, T.H. (2004) Trees or no trees? The environments of central and eastern Europe during the Last Glaciation. Quaternary Science Reviews, 23, 2369-2387.

Willis, K.J., Rudner, E. \& Sumegi, P. (2000) The full-glacial forests of central and southeastern Europe. Quaternary Research, 53, 203-213.

Wright, H.E. \& Thorpe, J.L. (2005) Climatic change and the origin of agriculture in the Near East. Global change in the Holocene (ed. by A. Mackay, R. Batterbee, J. Birks and F. Oldfield), pp. 49-62. Arnold, London.

Yasuda, Y., Kitigawa, H. \& Nakagawa, T. (2000) The earliest record of major anthropogenic deforestation in the Ghab valley, northwest Syria: a palynological study. Quaternary International, 73/74, 127-136.

van Zeist, W. \& Bottema, S. (1977) Palynological investigations in Western Iran. Palaeohistoria, 19, 19-86.

Zohary, M. (1973) Geobotanical foundation of the Middle East. Gustav Fisher Verlag, Stuttgart.

\section{SUPPLEMENTARY MATERIAL}

The following supplementary material is available for this article online:

Appendix S1 Identification of Celtis fruit stones and Juniperus seeds.

Figure S1 Celtis fruit stones and Juniperus seeds.

This material is available as part of the online article from: http://www.blackwell-synergy.com/doi/abs/10.1111/j.13652699.2007.01849.x

Please note: Blackwell Publishing is not responsible for the content or functionality of any supplementary materials supplied by the authors. Any queries (other than missing material) should be directed to the corresponding author for the article.

\section{BIOSKETCHES}

Enikö K. Magyari has research interests in Quaternary vegetation dynamics, environmental change, and human impact on the vegetation of south-east Europe. Her current work focuses on the palaeoenvironmental record of late-glacial and Holocene landscape transformations brought about by agriculture and pastoralism in two large river basins in eastern Hungary, south-east Bulgaria and north-west Turkey.

Brian Huntley is an ecologist and palaeoecologist with wideranging research interests in biogeography and environmental change. He has a particular interest in the late Quaternary dynamics of species distributions, and in how these dynamics have influenced present biogeographical patterns.

Editor: Glen MacDonald 